\title{
9. UPPER CRETACEOUS LARGER FORAMINIFER BIOSTRATIGRAPHY FROM WODEJEBATO GUYOT, SITES 873 THROUGH $877^{1}$
}

\author{
Isabella Premoli Silva, ${ }^{2}$ Alda Nicora, ${ }^{2}$ and Annie Arnaud Vanneau ${ }^{3}$
}

\begin{abstract}
Shallow-water limestones were recovered at five sites on Wodejebato Guyot. The age of these sediments, determined with larger benthic and planktonic foraminifers, ranges from middle late Campanian to late Maastrichtian. The most important and age-diagnostic larger foraminifers are Pseudorbitoides trechmanni, Omphalocyclus macroporus, Orbitoides sp., Asterorbis, and sulcoperculinids.

After the Late Cretaceous episode of volcanism, the volcanic island of Wodejebato subsided and was flooded in the late Campanian under shallow-marine conditions. The age of the inception of marine conditions is deduced from calcareous nannofossils at the base of the marine sequence at Sites 873 and 877 . A substantial carbonate platform became established shortly later, in the late Campanian, with a relatively deep-water environment of deposition covering the center of the lagoon.The platform continued to grow, and carbonate sedimentation in the early Maastrichtian extended from the center toward the platform edge, which became temporary and modestly bioconstructed. After this brief episode, shallower water conditions progressively affected both the lagoonal and platform edges, culminating with the temporary emergence of the Wodejebato platform. Shortly after this event, deeper water, open-marine conditions resumed over the entire platform, characterizing the topmost sediments recovered at the lagoonal and inner ridge sites. Carbonate sedimentation, however, continued at Wodejebato until the late Maastrichtian, as demonstrated by the shelf margin deposits recovered at outer ridge Sites 875 and 876 . The demise of the Wodejebato carbonate platform occurred before the end of the Maastrichtian, as indicated by the pelagic infilling of Maastrichtian age at the top of the carbonate succession. Pelagic sediments of early late Paleocene age imbedded in the capping $\mathrm{Mn}$-rich crust indicate that shortly after the cessation of the shallow-water carbonate sedimentation, Wodejebato Guyot was under an open-marine, oceanic environmental regime. The hiatus associated with the disconformity between the youngest shallow-water carbonates and the oldest calcareous plankton preserved in the Mn-crust is estimated to not exceed 3-4 m.y.
\end{abstract}

\section{INTRODUCTION}

Wodejebato (Sylvania) Guyot in the northern Marshall Islands was formed during the Early Cretaceous as a volcanic edifice (Lincoln et al., 1993). During the early Campanian (Pringle and Duncan, this volume), a second episode of volcanism produced the volcanic substratum, on which upper Campanian-Maastrichtian shallow-water limestones were deposited. Platform sedimentation ceased during the Maastrichtian, and pelagic foraminiferal and nannofossil oozes capped the guyot throughout the Tertiary and Quaternary (Premoli Silva, Haggerty, Rack, et al., 1993). The transition between the shallow-water sediments and the pelagic cap is marked by a thin layer rich in manganese and, to minor extent, phosphate embedding several generations of pelagic deposits mainly of Paleogene age (see Watkins et al., this volume) (Fig. 1),

Shallow-water limestones were recovered at five sites on Wodejebato Guyot during Ocean Drilling Program (ODP) Leg 144 (see site map preceding the title page). Site 873 was drilled in the center of the guyot. Sites 874 and 877 were drilled on the inner ridge that appears to be a constructional feature on the seismic lines northwestward of Site 873 . Sites 875 and 876 were drilled on the outer ridge, seaward of the inner ridge. The longitude, latitude, and water depth of the sites are shown in Table 1. These specific locations were chosen in an attempt to reconstruct the evolution of the guyot throughout its spacial extension.

Before Leg 144, shallow-water sediments of Late Cretaceous age had been recovered in dredges on the southern side of Wodejebato.

\footnotetext{
${ }^{1}$ Haggerty, J.A., Premoli Silva, I., Rack, F., and McNutt, M.K. (Eds.), 1995. Proc. ODP, Sci. Results, 144: College Station, TX (Ocean Drilling Program).

${ }^{2}$ Dipartimento di Scienze della Terra, Università di Milano, via L. Mangiagalli 34 I-20133 Milano, Italy.

${ }^{3}$ Institut Dolomieu, Université de Grenoble, rue Maurice Gignoux, F-30031 Grenoble Cedex. France.
}

These yielded skeletal debris totally comparable to that presently described from the drill holes (see Lincoln et al., 1993). Rather abundant shallow-water fossils of Campanian-Maastrichtian age were also recovered in coarse, resedimented deposits recovered in the abyssal plain of the Nauru Basin, located at Site 462 farther south of Wodejebato, during Deep Sea Drilling Program (DSDP) Leg 61 (Larson, Schlanger, et al., 1981). These latter deposits contained shallow-water foraminifers and skeletal debris, although of mixed age, but identical to those recovered in situ during the drilling campaign of Leg 144 (Premoli Silva and Brusa, 1981).

This study mainly deals with the larger foraminifers and, to a minor extent, with associated organisms (e.g., small foraminifers, red and green algae, corals, mollusks, echinoderms) from Sites 873 through 877 . The identification and distribution of the larger foraminifers, in addition to the calcareous nannofossils and planktonic foraminifers, allowed us to date the basal marine sediments and the shallow-water sequence, respectively (Figs. 2-6). On the basis of the benthic foraminiferal content and other associated organisms, including the planktonic foraminifers found in the sequence, an attempt was made to reconstruct a paleoecological model and to outline the environmental evolution of the Wodejebato platform.

\section{MATERIALS AND METHODS}

Of the 279 rock samples and "cuttings" of shallow-water limestones analyzed from 9 holes drilled at 5 sites on Wodejebato Guyot, 100 samples were from Site 873,63 were from Site 874,41 were from Site 875,31 were from Hole $876 \mathrm{~A}$, and 44 were from Site 877 . The identification of microfauna and associated organisms from the platform carbonates from all sites was based mainly on the examination of thin sections. Some isolated specimens were also recovered from "cuttings" (debris of limestones collected on a sieve as each section of the core was split), and oriented thin sections of some larger benthic foraminifers were made to analyze the internal (embryonic) 


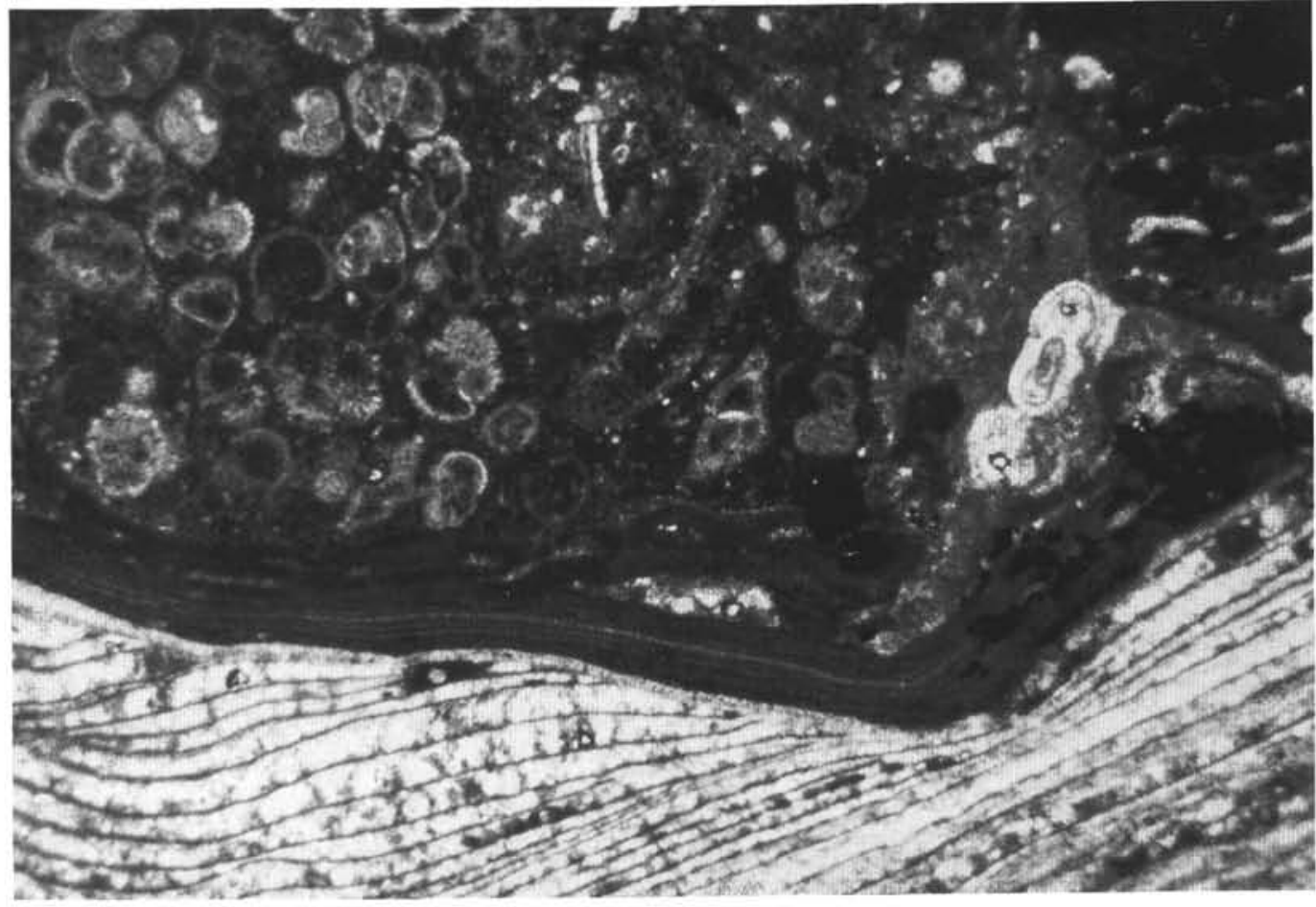

Figure 1. Photomicrograph of Maastrichtian rudist shell carpeted by encrusting corallinacean algae in contact with pelagic micrite rich in planktonic foraminifers of Zone P12, late middle Eocene. Sample 144-873B-8N-1, 4-8 cm, Wodejebato Guyot, magnification 35x.

Table 1. Geographic coordinates and water depth of Wodejebato Guyot sites.

\begin{tabular}{ccccc}
\hline Site & $\begin{array}{c}\text { Latitude } \\
(\mathrm{N})\end{array}$ & $\begin{array}{c}\text { Longitude } \\
(\mathrm{E})\end{array}$ & $\begin{array}{c}\text { Water } \\
\text { depth } \\
(\mathrm{mbsf})\end{array}$ & $\begin{array}{c}\text { Thickness } \\
(\mathrm{m})\end{array}$ \\
\hline 873 & $11^{\circ} 53.84^{\prime}$ & $164^{\circ} 55.20^{\prime}$ & 1334 & 93.5 \\
874 & $12^{\circ} 00.76^{\prime}$ & $164^{\circ} 55.22^{\prime}$ & 1374 & 172.7 \\
875 & $12^{\circ} 00.72^{\prime}$ & $164^{\circ} 56.44^{\prime}$ & 1409 & 125.8 \\
876 & $12^{\circ} 01.476^{\prime}$ & $164^{\circ} 55.90^{\prime}$ & 1399 & 145.4 \\
877 & $12^{\circ} 01.14^{\prime}$ & $164^{\circ} 55.30^{\prime}$ & 1355 & 182.8 \\
& & & & \\
\hline
\end{tabular}

characteristics. The "cuttings" samples in Tables 2 through 5 are listed below the lowermost centimeter recovered in any given section.

The distribution and abundance of benthic foraminifers, as well as selected sedimentological features, are shown in Tables 2 through 5. The distribution of all the identified organisms are plotted as abundance curves on Figures 7 through 11. Organism abundance in Figures 7 through 11 was estimated as follows: $1=$ one individual or fragment; $2=2-3$ individuals or fragments; $3=4-5$ individuals or fragments; $4=6-7$ individuals or fragments; $5=8-9$ individuals or fragments; $6=$ common individuals or fragments; $7=$ common to frequent individuals or fragments; $8=$ frequent individuals or fragments; 9 = frequent to abundant individuals or fragments; $10=$ abundant individuals or fragments; $11=$ very abundant individuals or fragments; and 12 = extremely abundant individuals or fragments. Some of the significant benthic foraminifers, within their characteristic microfacies, are illustrated in Figure 12 and Plates 1 through 5.

\section{BIOSTRATIGRAPHIC EVENTS AND AGE}

The shallow-water organisms from all of the sites drilled on Wodejebato Guyot show a scattered distribution because of facies changes occurring in the development of the carbonate platform and the poor recovery that resulted in an incomplete distribution of organisms and facies.
The larger foraminifers, some of which occur in specific intervals, form the main age-diagnostic organisms. The pseudorbitoidids, asterorbids, sulcoperculinids, and Omphalocyclus, as well as the rudists, indicate a generalized Campanian-Maastrichtian age range, although Omphalocyclus is exclusively restricted to the Maastrichtian. Formal zonal schemes based on larger foraminiferal species evolution were constructed by Van Gorsel (1978). Age constraints by means of correlation with planktonic organisms are still tentative, and calibration points between Upper Cretaceous larger foraminifers and calcareous plankton are few (Van Hinte, 1976; Van Gorsel, 1978).

A better biostratigraphic resolution can be obtained by using evolutionary stages of the embryonic nepionic chamber arrangement in megalospheric larger foraminifers. Poor recovery, poor preservation, and the restricted occurrences of the larger foraminifers at the Wodejebato sites, however, prevented a detailed analytical study of the nepionic stages, as well as identification at a specific level. Some help in constraining the age of the recovered sequences was obtained from the associated planktonic organisms. Although never abundant, these planktonic organisms are present at most of the sites (see Premoli Silva, Haggerty, Rack, et al., 1993; Erba et al., this volume). Significant foraminiferal events recognized at Wodejebato Guyot are as follows (from bottom to top) (Tables 2-5 and Figs. 2-6).

The oldest assemblage is dominated by Pseudorbitoides trechmanni sporadically associated with Vaughanina. The former species occurs in abundance in Holes 873A (Samples 144-873A-11R-2, 135$139 \mathrm{~cm}$, to $-11 \mathrm{R}-2,113-116 \mathrm{~cm}$ ), 874B (Samples 144-874B-20R-1, 16-22 cm, to -19R-1, 7-10 cm), and 877A (Samples 144-877A-20R$1,77-78 \mathrm{~cm}$, to $-19 \mathrm{R}-1,27-30 \mathrm{~cm})$. Rare specimens were also recorded in Hole 875C (Samples 144-875C-14M-1, 59-62 cm, and $-14 \mathrm{M}-1,59-61 \mathrm{~cm})$.

Pseudorbitoides trechmanni overlaps with Asterorbis in the upper part of its range, in Sample 144-873A-11R-2, 135-139 cm, Samples 144-874B-19R-1, 11-13 and 7-10 cm, and Sample 144-877A-20R-1, 0-7 cm (and possibly Sample 144-877A-19R-1, 27-30 cm).

Omphalocyclus macroporus appears in Cores 144-873A-1R, 144873B-9N, 144-877A-1R, 144-875C-12M, and 144-876B-14R, always 


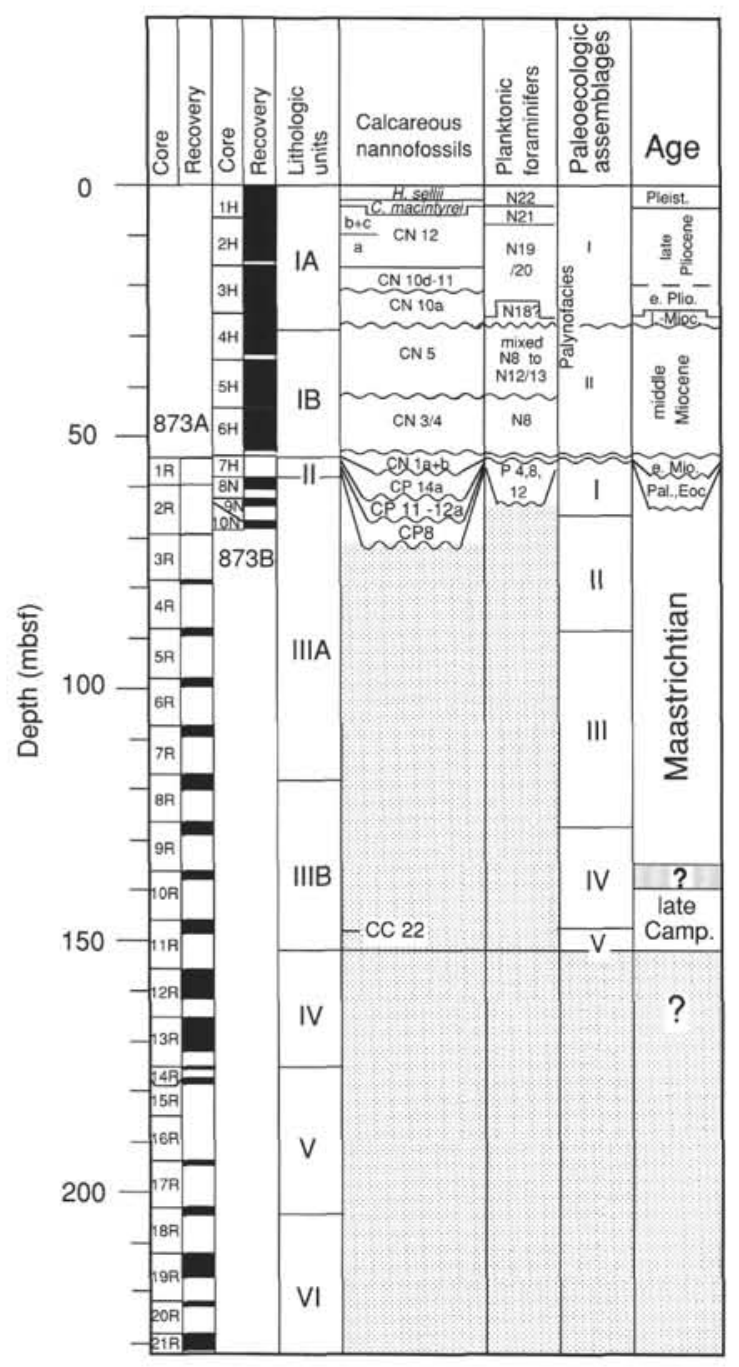

Figure 2. Synthetic log of shallow-water limestones drilled in Holes 873A and $873 \mathrm{~B}$ on the summit of Wodejebato Guyot, with core recovery, lithologic units, and paleoecological assemblages plotted vs. calcareous plankton occurrence and age.

in association with Sulcoperculina and Asterorbis. In Hole 875C, this species extends with certainty up to Core $144-875 C-9 M$. It was not recorded in Hole 874B.

Rare individuals of Orbitoides sp. occur in Samples 144-877A$18 \mathrm{R}-1,25-28 \mathrm{~cm}$, and $-15 \mathrm{R}-1,22-26 \mathrm{~cm}$. It was not found in any of the other sites. They display some similarities with Orbitoides medius (see Appendix) (Fig. 7 and Pl. 2, Figs. 4 and 5).

Individuals possibly belonging to the genus Lepidorbitoides occur in Hole $875 \mathrm{C}$ along with Omphalocyclus; it is possibly also present at Site 876. It is absent at Sites 873, 874, and 877.

Sulcoperculinids are a common component of the assemblages at all sites. The most common species are Sulcoperculina vermunti, $S$. globosa, and $S$. obesa, with $S$. dickersoni less common.

The assemblages at the top of Sites 875 and 876 , however, are devoid of Sulcoperculina (from Core 144-875C-2M and top of Core 144-876A-7R upward, respectively), whereas it occurs until the topmost layers in the other three sites.

Asterorbis, mainly ascribed to Asterorbis rooki, is present from close to the base to the top of the carbonate platform sequence at all sites.

Vidalina sp. cf. V. hispanica occurs at all sites except Site 876. Its facies-related discontinuous distribution appears to be similarly reproduced in Holes 873A (Cores 144-873A-7R to -2R), 874B (Cores

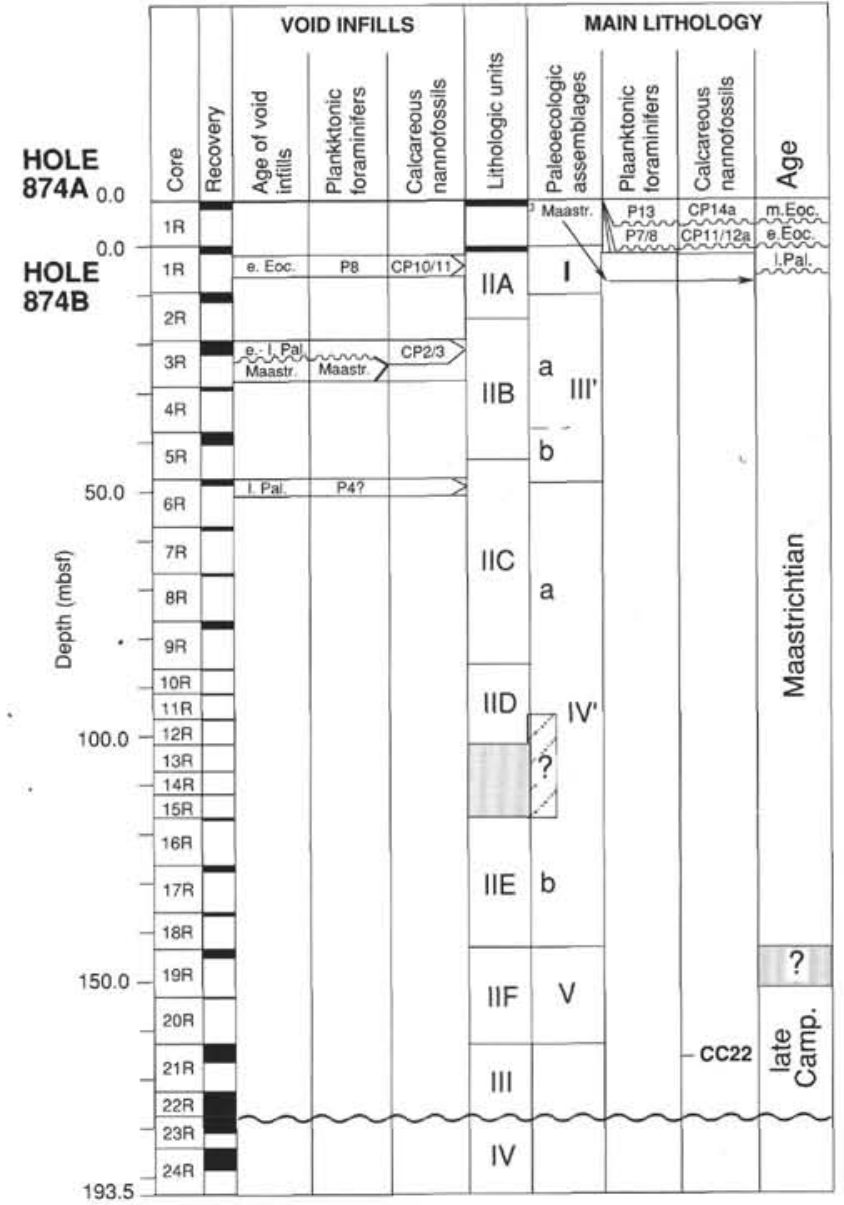

Figure 3. Synthetic log of shallow-water limestones drilled in Holes 874A and 874B on the inner ridge of Wodejebato Guyot, with core recovery, lithologic units, and paleoecological assemblages plotted vs. calcareous plankton occurrence and age.

144-874B-5R to -2R), and 877A (Cores 144-877A-19R to -2R). It also occurs in a single sample at Site 875 (Sample 144-875C-12M-2, $24-28 \mathrm{~cm}$ ).

Dicyclina sp. cf. D. schlumbergeri occurs in Hole 873A (Cores 144-873A-11R through -9R). Few specimens are present in Hole 874B (Sample 144-874B-6R-1, 127-130 cm), and a single specimen is recorded in Hole 876A (Sample 144-876A-9R-1, 10-14 cm).

Sporadic Montsechiana sp. occurs in Holes 873A (Cores 144$873 \mathrm{~A}-10 \mathrm{R}$ to $-4 \mathrm{R}$ ), $874 \mathrm{~B}$ (Cores $144-874 \mathrm{~B}-6 \mathrm{R}$ to $-5 \mathrm{R}$ ), and $877 \mathrm{~A}$ (Cores 144-877A-2R to -1R).

Idalina antiqua was recorded only in Hole 873A (Sample 144$873 \mathrm{~A}-4 \mathrm{R}-1,36-40 \mathrm{~cm}$ ).

Although most of the species mentioned above are known to occur in the Campanian-Maastrichtian interval, some of them display a more restricted range:

1. Pseudorbitoides trechmanni occurs in Jamaica associated with late Campanian calcareous nannofossils (Zones CC22 and lower CC23) (Krijnen, 1972; Krijnen et al., 1993). A similar distribution was given by Van Gorsel (1978); however, on the basis of new calibrations, its age is late Campanian instead of early Maastrichtian (see discussion in Erba et al., this volume).

2. Omphalocyclus macroporus first occurs in the Maastrichtian (Van Hinte, 1976; Van Gorsel, 1978).

3. According to Van Gorsel (1978) and Neumann (1993), Orbitoides medius ranges from the upper Campanian to the upper Maas- 
Table 2. Stratigraphic ranges and relative abundance of Campanian-Maastrichtian foraminifers, calcareous algae, other organisms, mineral grains, and sedimentary features from shallow-water limestones drilled in Holes 873A and 873B (summit of Wodejebato Guyot).

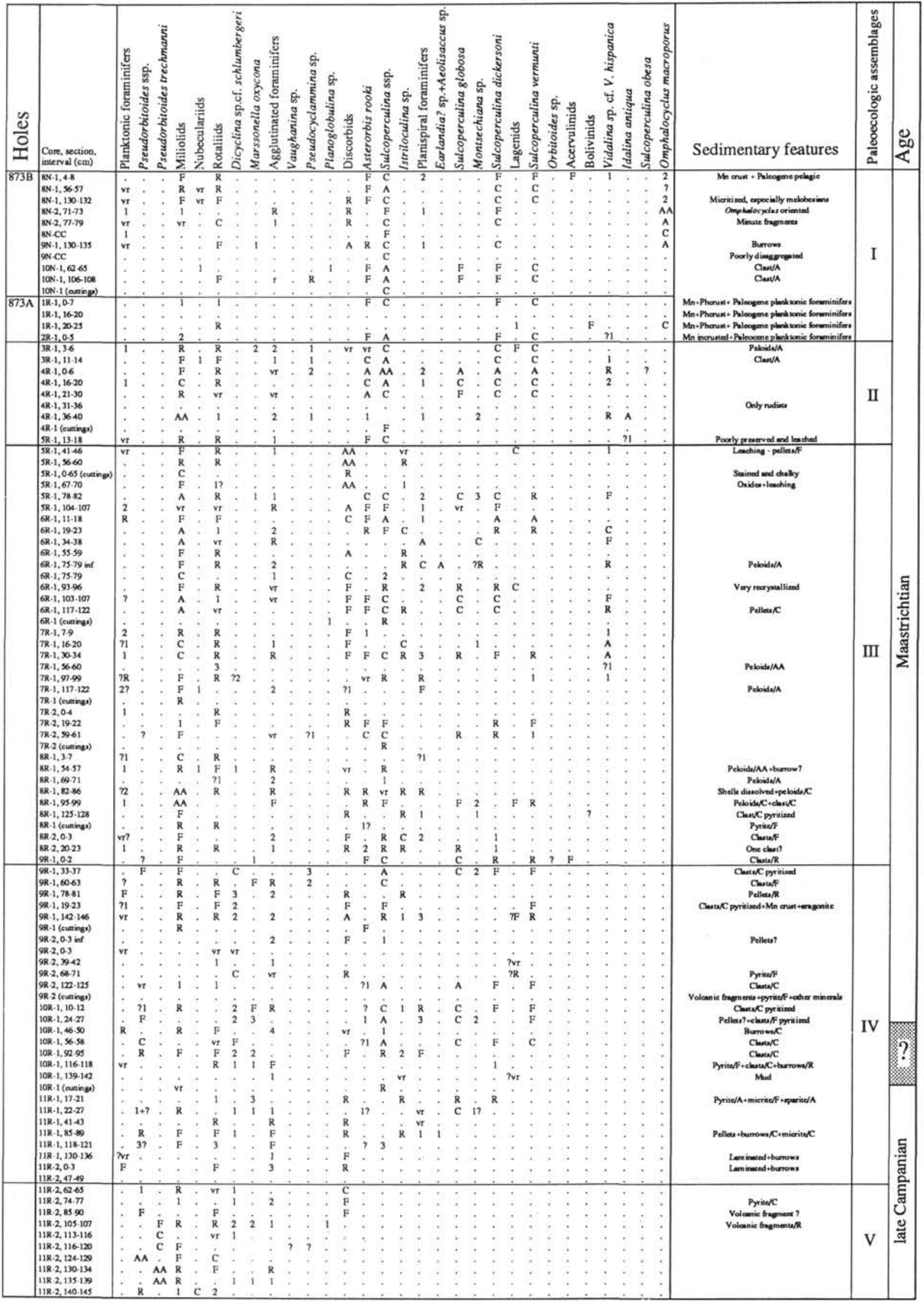

Notes: Estimated abundance as follows. \# number of specimens, $\mathrm{vr}=$ very rare, $\mathrm{R}=\mathrm{rare}, \mathrm{F}=\mathrm{few}, \mathrm{C}=\mathrm{common}, \mathrm{A}=\mathrm{abundant}$, and $\mathrm{AA}=\mathrm{very}$ abundant. inf $=$ infilling. 


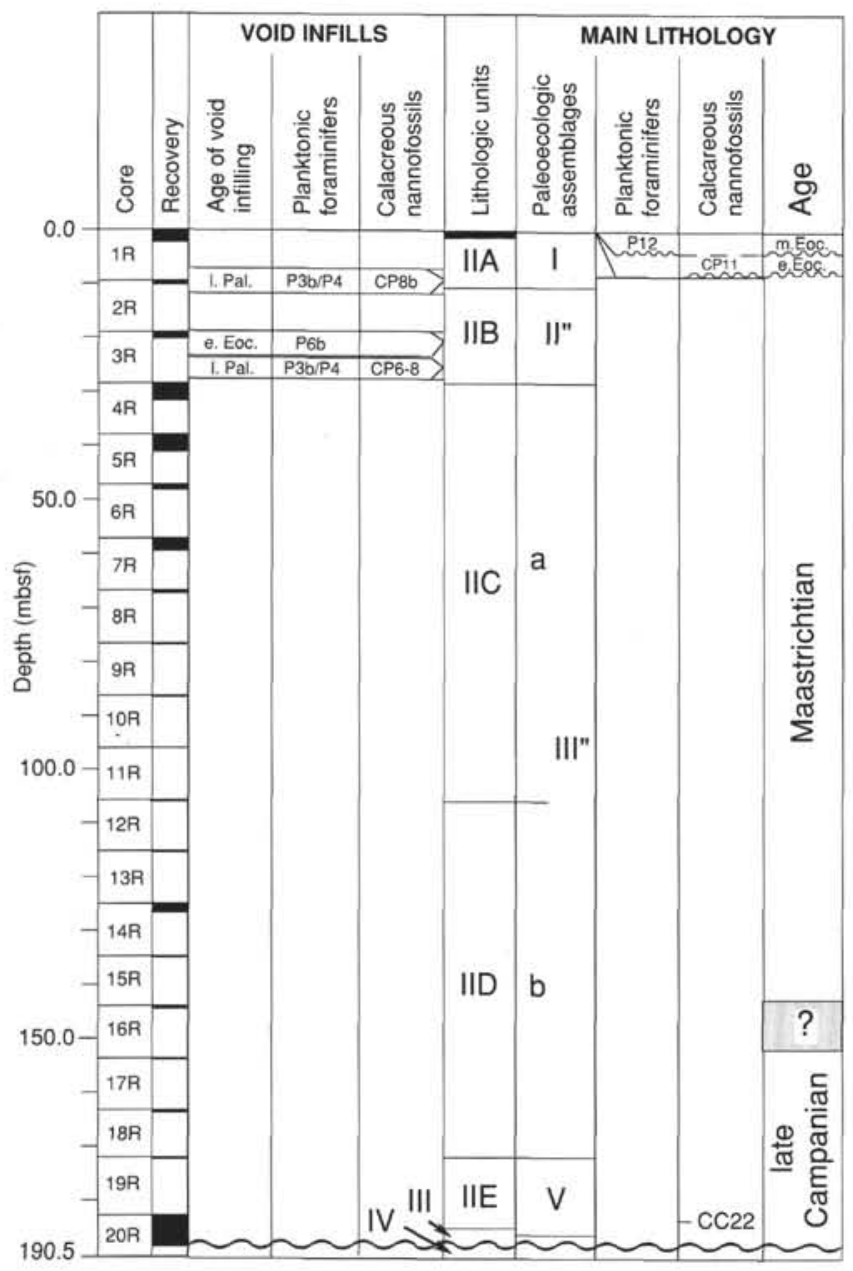

Figure 4. Synthetic log of shallow-water limestones drilled in Hole 877A on the inner ridge of Wodejebato Guyot, with core recovery, lithologic units, and paleoecological assemblages plotted vs. calcareous plankton occurrence and age.

trichtian. The embryonic values appear to be consistent with those recorded around the Campanian/Maastrichtian boundary (Neumann, 1993) (see Appendix).

4. The genus Lepidorbitoides, if correctly identified, evolves from Helicorbitoides in the Campanian and ranges up throughout the Maastrichtian.

5. All species of Sulcoperculina range from the Campanian to the Maastrichtian, but their level of extinction is not calibrated (see Ellis and Messina, 1967).

6. Asterorbis rooki, the species to which all asterorbids should be referred (Van Gorsel, 1978), ranges from the Campanian to the Maastrichtian; its extinction level, however, is not known.

7. Dicyclina schlumbergeri is known to extend up to the Maastrichtian.

8. Vidalina hispanica, Montsechiana sp., and Idalina antiqua are long-ranging species, and their precise extinction levels are poorly known.

Taking into account the above ranges and the occurrence of the best age-diagnostic taxa within the Wodejebato succession at the various sites, the inception of the shallow-water carbonate sedimentation is definitely late Campanian in age. This is supported by the occurrence of Pseudorbitoides trechmanni at the bases of Holes 873A, $874 \mathrm{~B}$, and $877 \mathrm{~A}$, in association with calcareous nannofossils of Zone $\mathrm{CC} 22$ at Site 877 (Erba et al., this volume). The other firm point is the occurrence of Omphalocyclus at the top of the shallow-water limestone unit at Sites 873 and 877 , which indicates that these levels are

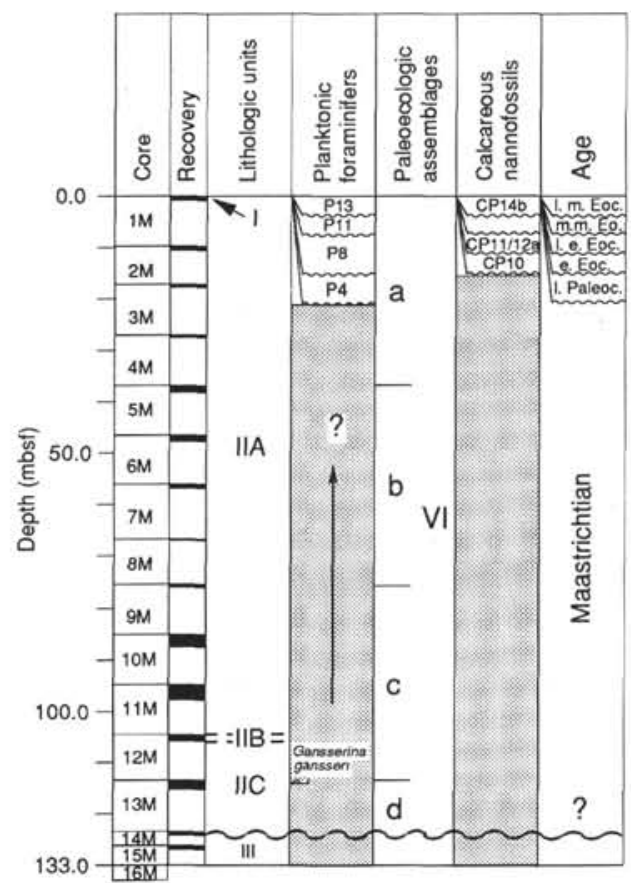

Figure 5. Synthetic log of shallow-water limestones drilled in Hole $875 \mathrm{C}$ on the outer ridge of Wodejebato Guyot, with core recovery, lithologic units, and paleoecological assemblages plotted vs. calcareous plankton occurrence and age.

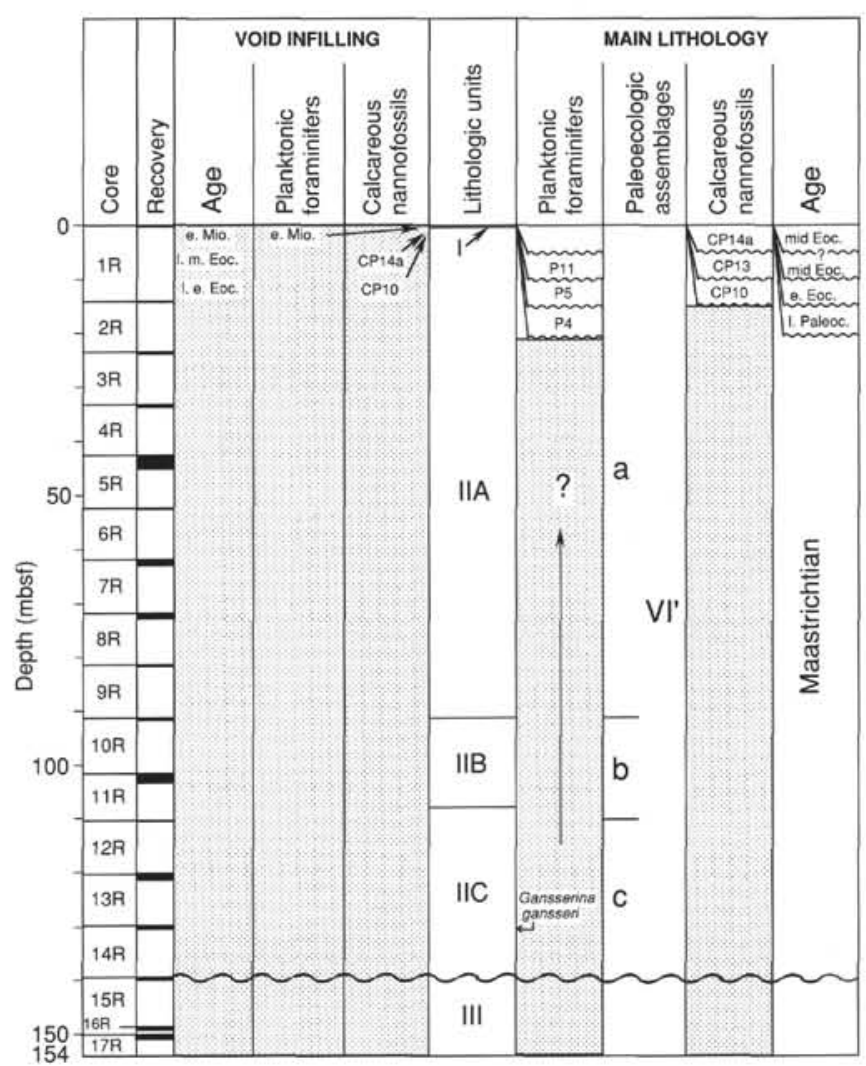

Figure 6. Synthetic log of shallow-water limestones drilled in Hole 876A on the outer ridge of Wodejebato Guyot, with core recovery, lithologic units, and paleoecological assemblages plotted vs. calcareous plankton occurrence and age. 
Table 3. Stratigraphic ranges and relative abundance of Campanian-Maastrichtian foraminifers, calcareous algae, other organisms, mineral grains, and sedimentary features from shallow-water limestones drilled in Holes 874A and 874B (inner ridge of Wodejebato Guyot).

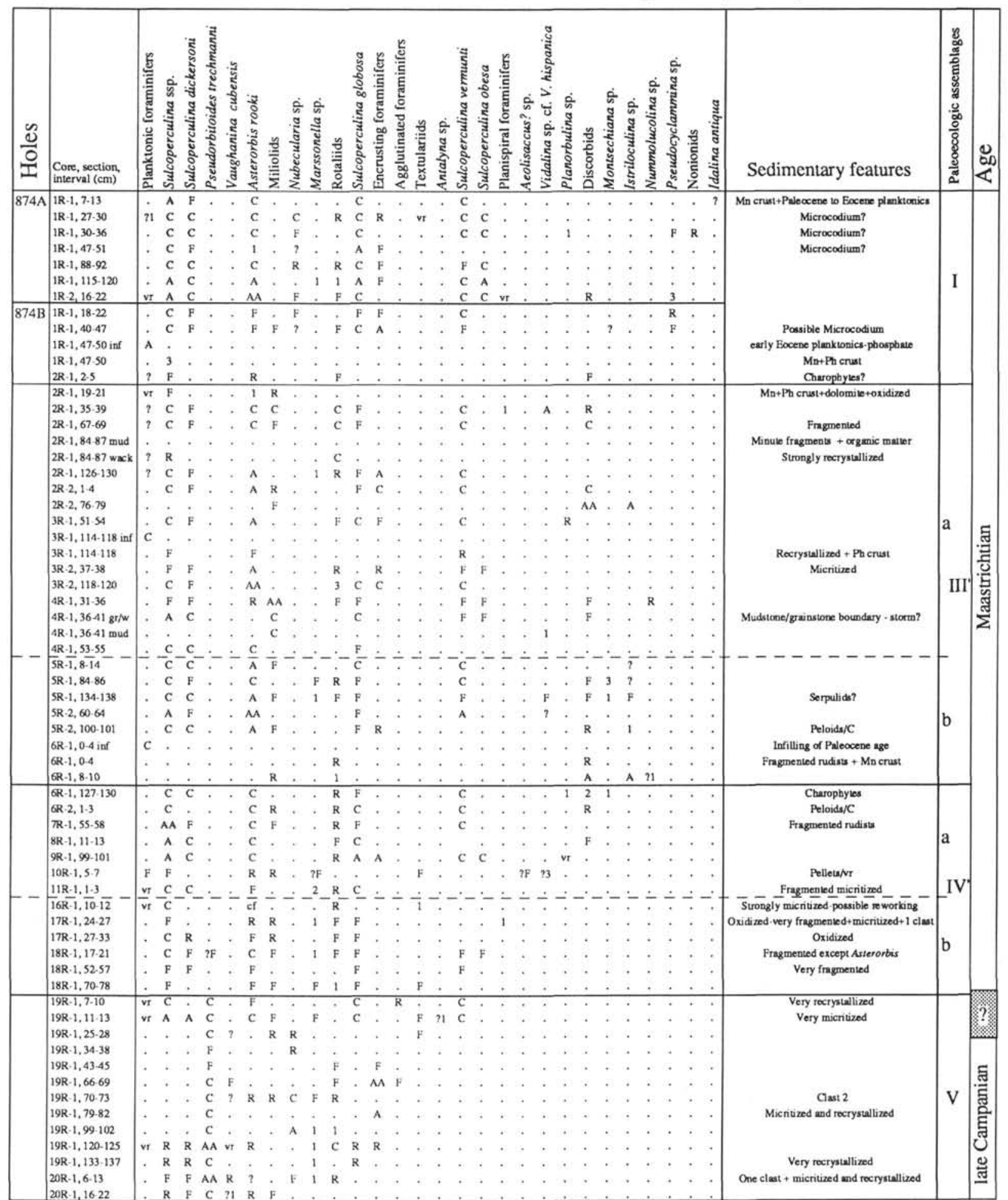

Notes: Estimated abundance as follows: $\#=$ number of specimens, $v r=$ very rare, $R=r a r e, F=$ few, $C=$ common, $A=a b u n d a n t$, and $A A=$ very abundant. Sample designation as follows; inf $=$ infilling, mud $=$ mudstone, wack and $\mathrm{w}=$ wackestone, and $\mathrm{gr}=$ grainstone,

definitely Maastrichtian in age. This age is further supported by the presence of planktonic foraminifers attributable to the Gansseri gansseri group, which is more commonly represented in the Maastrichtian part of the nominal zone (see Erba et al., this volume).

The paucity of age-diagnostic foraminifers in the central portion of the carbonate succession prevents the correct placement of the Campanian/Maastrichtian boundary on a biostratigraphic base. Ac- cording to the strontium isotope curve, recently calibrated on welldated sections from northern Europe and southern England (McArthur et al., 1992, 1993), strontium isotope values typical for the Maastrichtian were measured at $80 \mathrm{~m}$ below seafloor (mbsf) at Site 877 , possibly extending down to about $145 \mathrm{mbsf}$ and around $140 \mathrm{mbsf}$ at Site 874 (see Wilson et al. and Quinn et al., both in this volume). This implies that most of the shallow-water limestone recovered at these 
Table 4. Stratigraphic ranges and relative abundance of Campanian-Maastrichtian foraminifers, calcareous algae, other organisms, mineral grains, and sedimentary features from shallow-water limestones drilled in Hole 877A (inner ridge of Wodejebato Guyot).

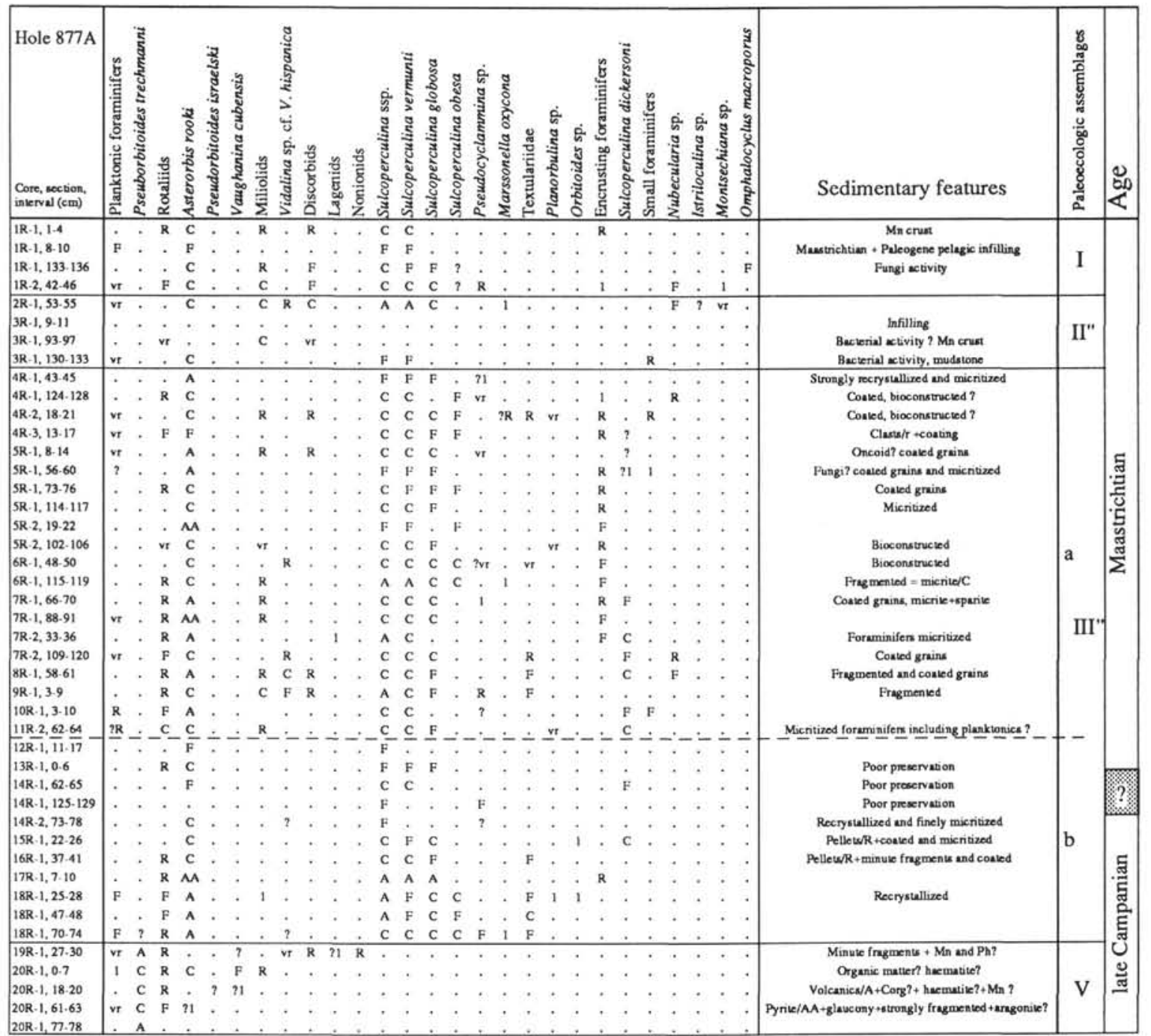

Notes: Estimated abundance as follows: $\#=$ number of specimens, $v r=$ very rare, $\mathrm{R}=$ rare, $\mathrm{F}=$ few, $\mathrm{C}=$ common, $\mathrm{A}=\mathrm{abundant}$, and $\mathrm{AA}=\mathrm{very}$ abundant.

sites is Maastrichtian in age, and only the lowermost layers are attributable to the late Campanian. This age is consistent with the occurrence of Orbitoides sp. aff. O. medius in Core 144-877A-15R at $135 \mathrm{mbsf}$ (see above). We can extrapolate that most of the carbonate succession at Site 873 (no material suitable for strontium analysis was recovered at that site) is Maastrichtian in age (see Fig. 13). The Sr isotope values obtained from Sites 874 and 877 (Wilson et al., this volume; Quinn et al., this volume) indicate that the topmost part of the shallow-water limestone at Site 874 is definitely coeval with that from Sites 873 and 877. This correlation can be inferred from facies similarities, carbonate platform evolution, and the similar distribution of Vidalina sp. cf. $V$. hispanica, a minor constituent of foraminiferal assemblages, in Sites 874 and 877 (see Fig. 13). It was not supported, however, by the presence of Omphalocyclus (not found at Site 874, possibly because of poor recovery).

The first occurrence (FO) of Omphalocyclus macroporus was found in Hole $875 \mathrm{C}$ less than $10 \mathrm{~m}$ above the base of the carbonate sequence; in Hole 876A, it was less than $2 \mathrm{~m}$ above the base. These data suggest that most of the recovered succession in these holes is Maastrichtian in age, and the succession is younger than that recovered at Sites 873, 874, and 877. The interval below the FO of Omphalocyclus macroporus in Hole $875 \mathrm{C}$ yielded abundant Pseudorbitoides trechmanni in the lowermost two samples and assemblages rich in Asterorbis rooki and sulcoperculinids in the remaining portion.
Two alternative interpretations may be suggested to correlate this interval from Hole $875 \mathrm{C}$ with those of the other holes: (1) the lowermost part of the carbonate sequence in Hole $875 \mathrm{C}$ can be correlated with the bottom of the carbonate sequence at Sites 873, 874, and 877, so that most of the lower Maastrichtian sediments recorded at these sites are missing at Site 875 because of a major hiatus (within Core 144-875C-13M?); and (2) Pseudorbitoides trechmanni is reworked and the lower sediments of Hole 875C, below the FO of Omphalocyclus macroporus, are correlatable to the uppermost parts of Sites 873, 874 , and 877 , in which case the hiatus occurs between the shallowwater carbonate unit and the underlying basalt.

The second interpretation may be the most likely one in Hole 876 A because Omphalocyclus macroporus occurs in this hole $2 \mathrm{~m}$ above the base of the carbonate sequence, and Maastrichtian planktonic foraminifers were found just below this horizon (see Premoli Silva, Haggerty, Rack, et al., 1993; Erba et al., this volume). We infer, therefore, that almost the entire carbonate sequence recovered at Sites 873,874 , and 877 is missing in this hole as the result of a hiatus between the carbonate unit and the underlying basalt.

Planktonic foraminifers were recorded from all of the sites in Wodejebato, but they are scattered throughout the sequence and never abundant. The most continuous record was observed at the outer ridge, Sites 875 and 876 , particularly at the latter (see Tables 2 through 6). Most of the species identified have a range spanning the 


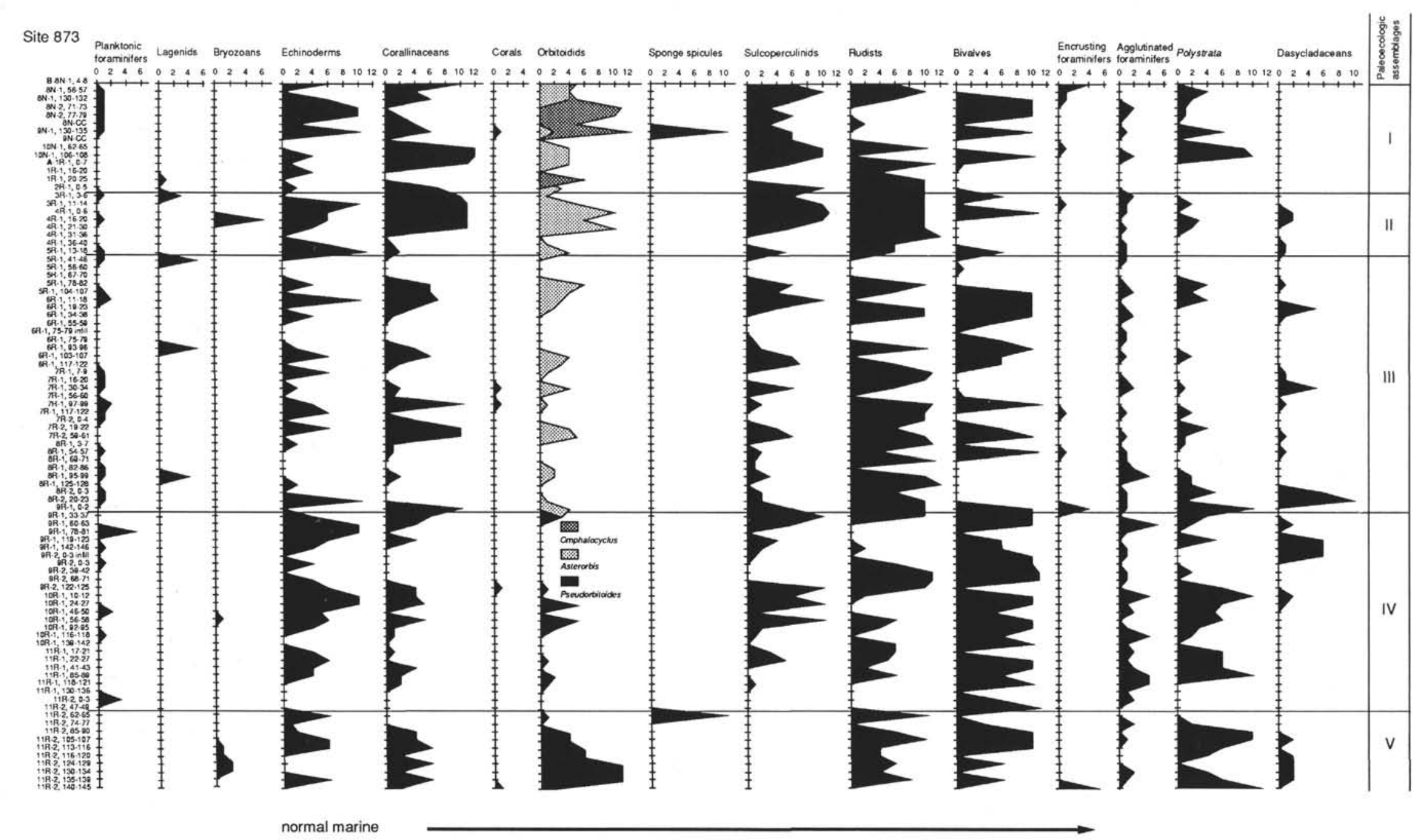

Figure 7. Abundance curves of the organisms from the shallow-water carbonate succession recovered at Wodejebato Guyot (Site 873), arranged according to their paleoenvironmental significance (normal marine on the left to more restricted on the right). Samples as in Table 2. See text for scale explanation. 


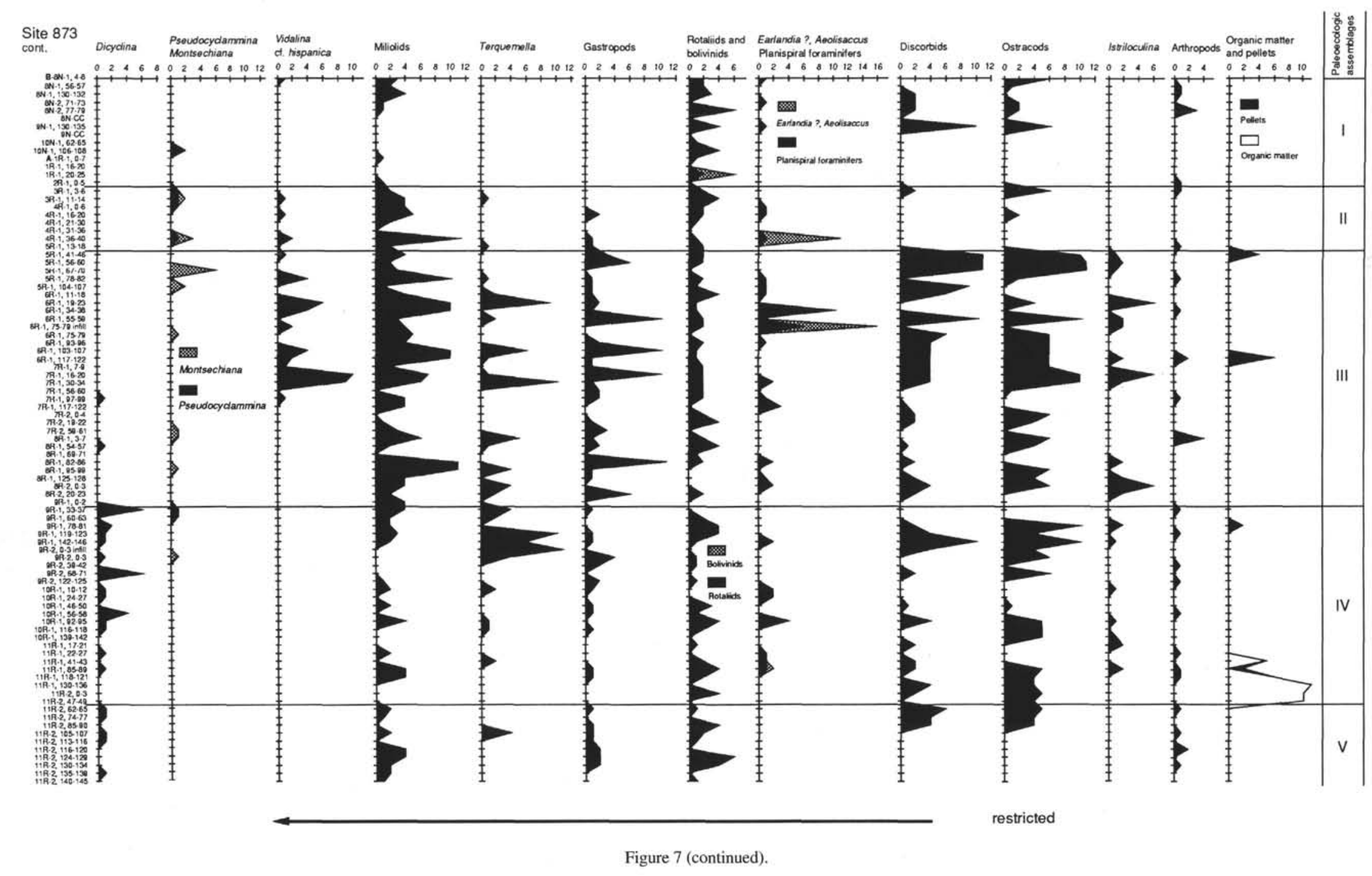




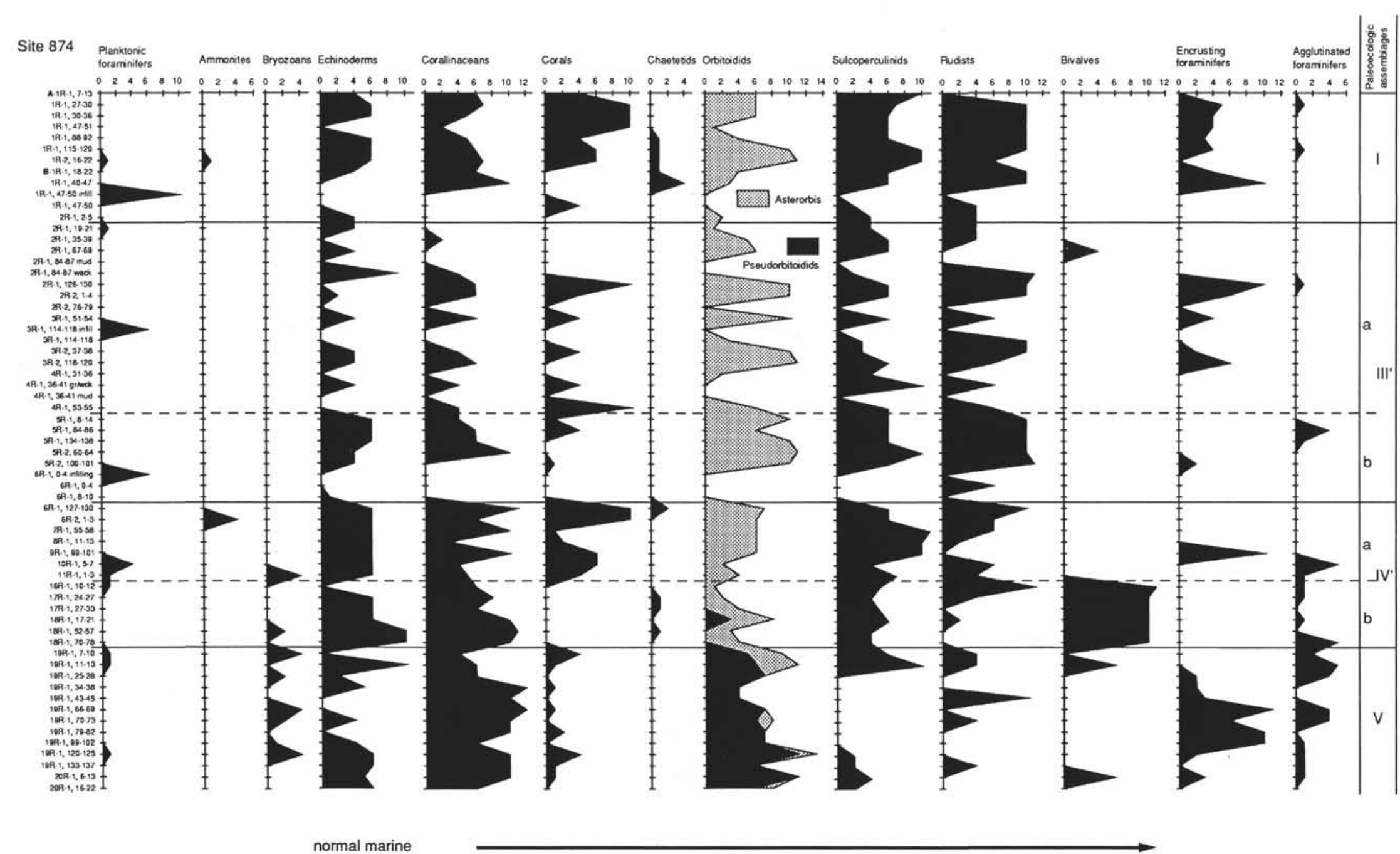

Figure 8. Abundance curves of the organisms from the shallow-water carbonate succession recovered at Wodejebato Guyot (Site 874), arranged according to their paleoenvironmental significance (normal marine on the left to more restricted on the right). Samples as in Table 3. See text for scale explanation. 


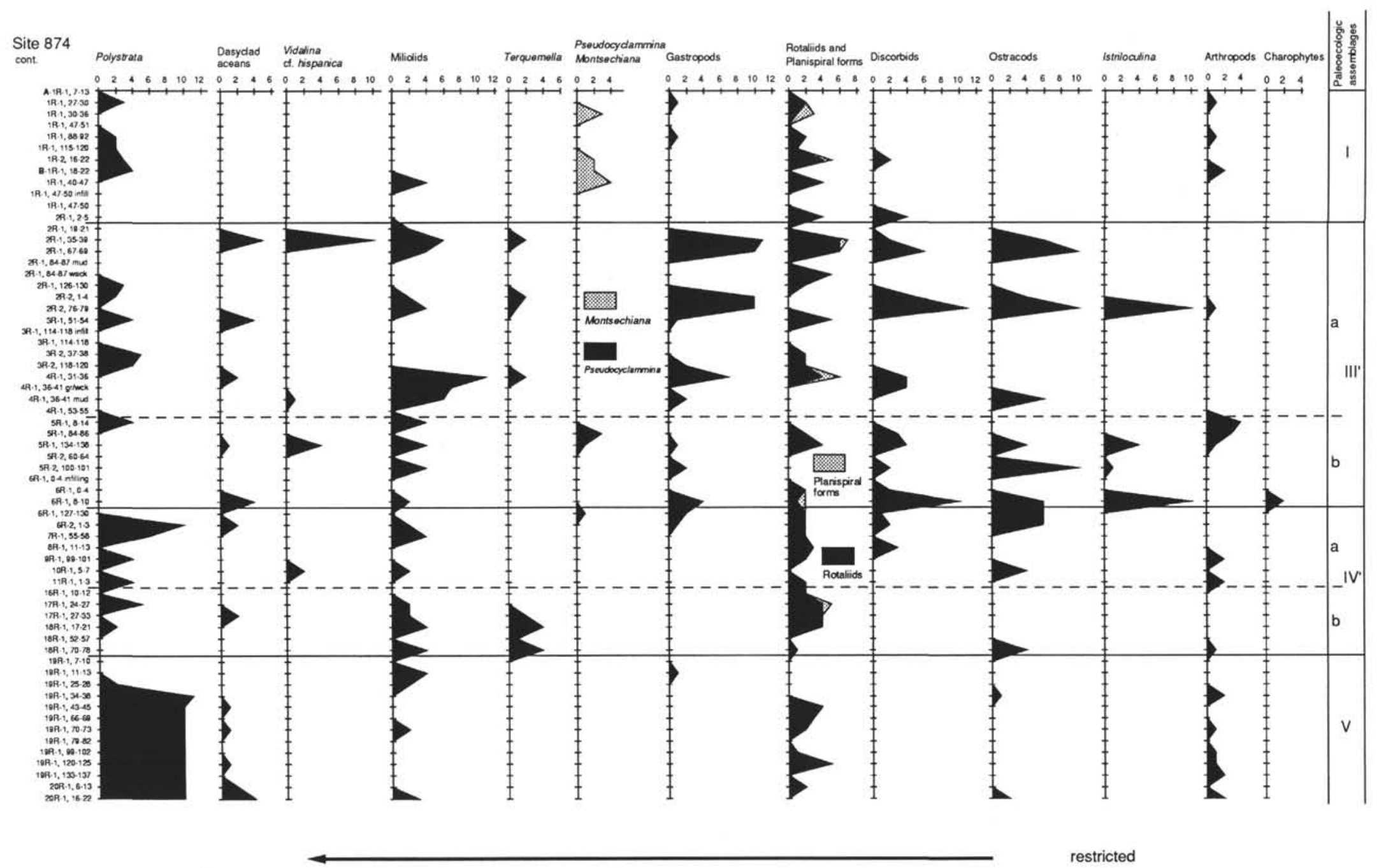

Figure 8 (continued). 


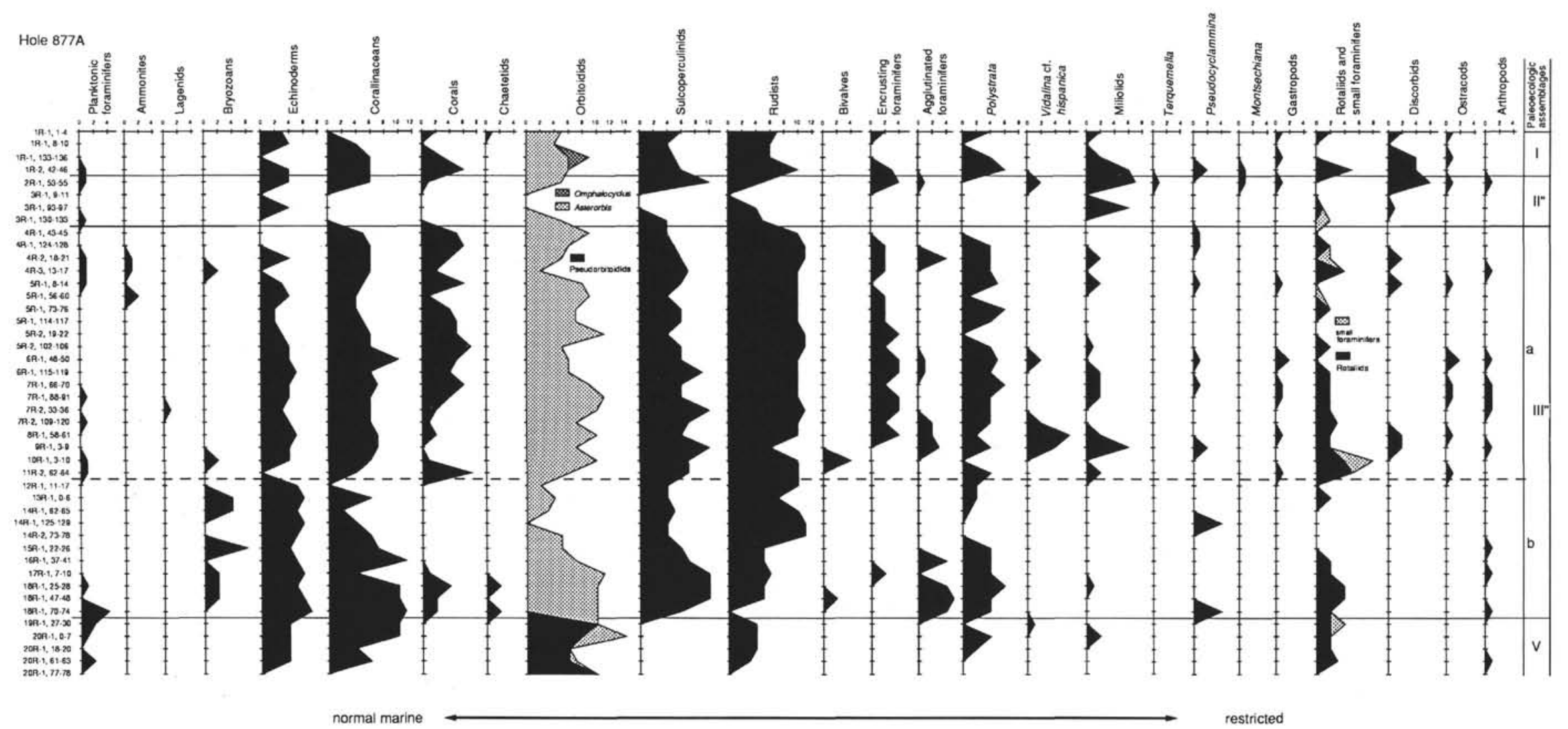

Figure 9. Abundance curves of the organisms from the shallow-water carbonate succession recovered at Wodejebato Guyot (Site 877), arranged according to their paleoenvironmental significance (normal marine on the left to more restricted on the right). Samples as in Table 4. See text for scale explanation. 
Table 5. Stratigraphic ranges and relative abundance of Campanian-Maastrichtian foraminifers, calcareous algae, other organisms, mineral grains, and sedimentary features from shallow-water limestones drilled in Hole $875 \mathrm{C}$ (outer ridge of Wodejebato Guyot).

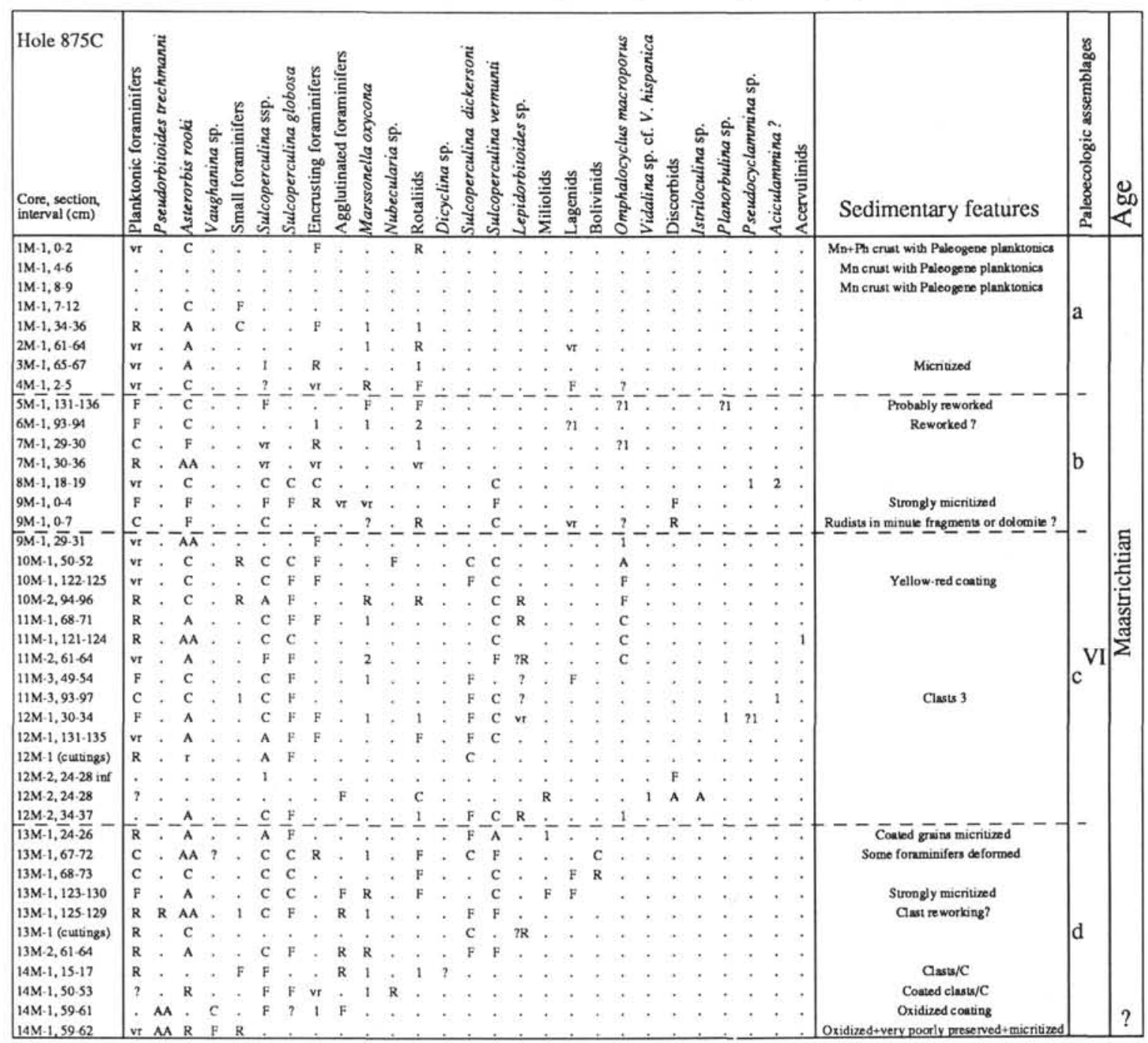

Notes: Estimated abundance as follows: $\#=$ number of specimens, $\mathrm{vr}=$ very rare, $\mathrm{R}=$ rare, $\mathrm{F}=$ few, $\mathrm{C}=$ common, $\mathrm{A}=\mathrm{abundant}$, and $\mathrm{AA}=\mathrm{very}$ abundant.

Campanian to the Maastrichtian, except for the Gansserina gansseri group, which appears in the uppermost Campanian and ranges up to the base of the upper Maastrichtian Abathomphalus mayaroensis Zone. The first representatives of this group are recorded in all sites just slightly before or contemporaneous with the FO of Omphalocyclus macroporus, which confirms the correlation of the Wodejebato sites as suggested by the larger foraminifers (Fig. 13) (see Erba et al., this volume).

The last occurrence (LO) of the sulcoperculinids occurs $25 \mathrm{~m}$ below the top of the carbonate sequence in Hole $875 \mathrm{C}$ and about 90 $\mathrm{m}$ below the top of the carbonate sequence in Hole 876A (Fig. 13). To explain the difference in thickness of the sedimentary deposits above the horizon of this event, we suspect that the top $65 \mathrm{~m}$ of the sequence in Hole $875 \mathrm{C}$ is missing as a result of erosion.

The top of the most complete succession in Hole 876A is definitely Maastrichtian in age. However, the poor biostratigraphic constraint based either on larger or planktonic foraminifers prevents establishing when during the Maastrichtian the carbonate sedimentation on Wodejebato Guyot ceased. The LO of the sulcoperculinids is not calibrated with any planktonic events, as mentioned above, and the planktonic foraminifer assemblages are devoid of Racemiguembelina fructicosa and Abathomphalus mayaroensis, the marker species of the uppermost Maastrichtian (see Erba et al., this volume). The relative abundance of various rugoglobigerinids in the upper portion of the carbonate sequence at these sites would indicate that these upper portions are probably late Maastrichtian in age (see Premoli Silva and Sliter, 1994). Cavity fillings at Site 874 (Samples 144874B-3R-1, 114-118 cm) yielded a few planktonic foraminifers of Maastrichtian age. Although no marker species were found, this may indicate that the demise of the carbonate platform at Wodejebato Guyot occurred before the end of the Cretaceous.

\section{PALEOECOLOGIC ASSEMBLAGES}

From a paleoecological point of view, the foraminifer-algalmacrofossil assemblages recovered from the five drill sites on Wodejebato Guyot reflect shallow-water platform environments ranging from a somewhat restricted lagoon to a fully normal marine environment. During its life, the Wodejebato platform experienced an intermittent short period of emersion, as demonstrated by the occurrence of cavities infilled with intraformational sediments (Premoli Silva, Haggerty, Rack, et al., 1993). The interpretation of the depositional environment is supported by fluctuations in the diversity and abundance of the whole micro- and macrofauna and flora throughout the recovered succession. Higher diversity assemblages indicate more open-marine conditions, whereas the lower diversity assemblages point to a restricted lagoonal environment. 


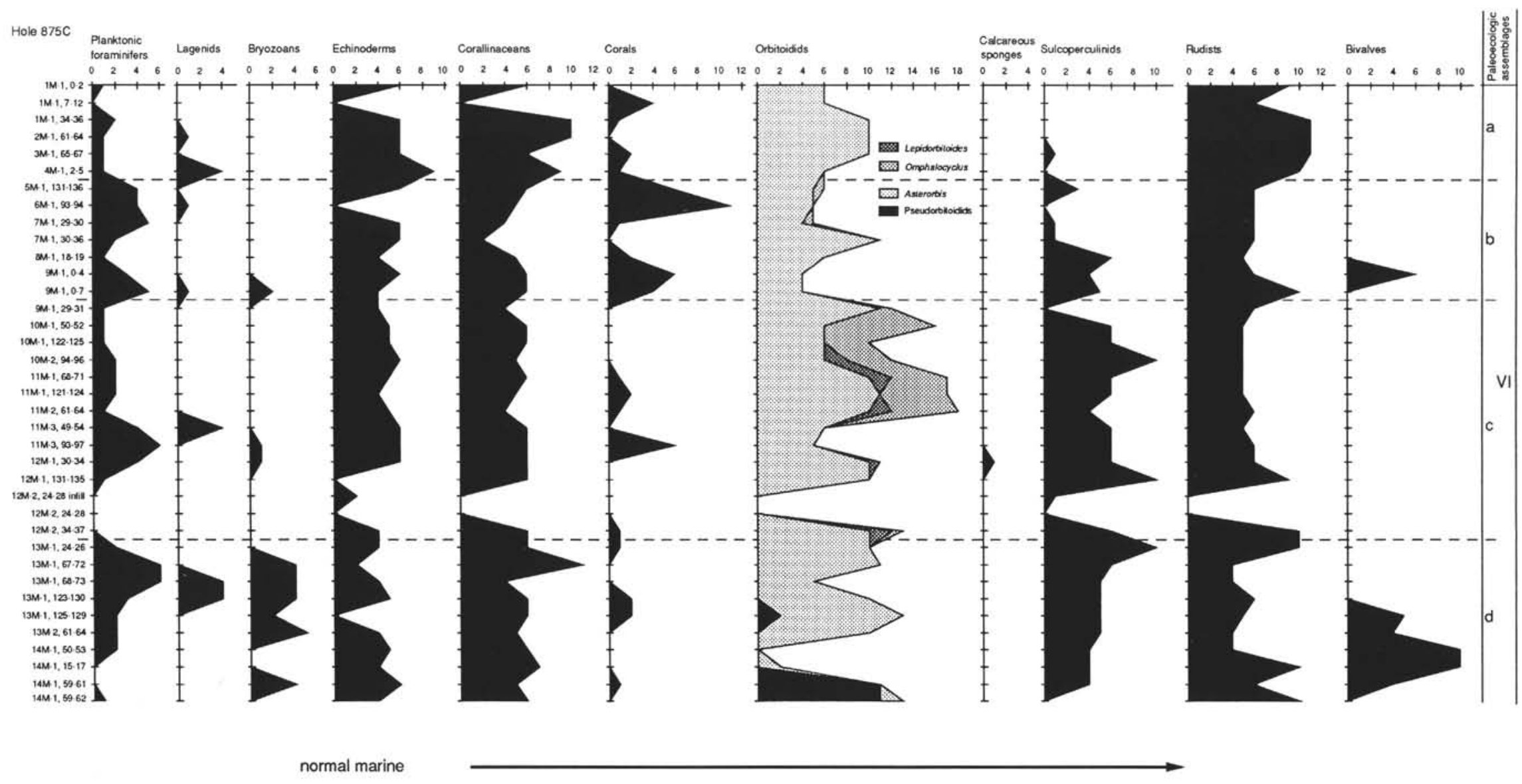

Figure 10. Abundance curves of the organisms from the shallow-water carbonate succession recovered at Wodejebato Guyot (Site 875), arranged according to their paleoenvironmental significance (normal marine on the left to more restricted on the right). Samples as in Table 5. See text for scale explanation. 


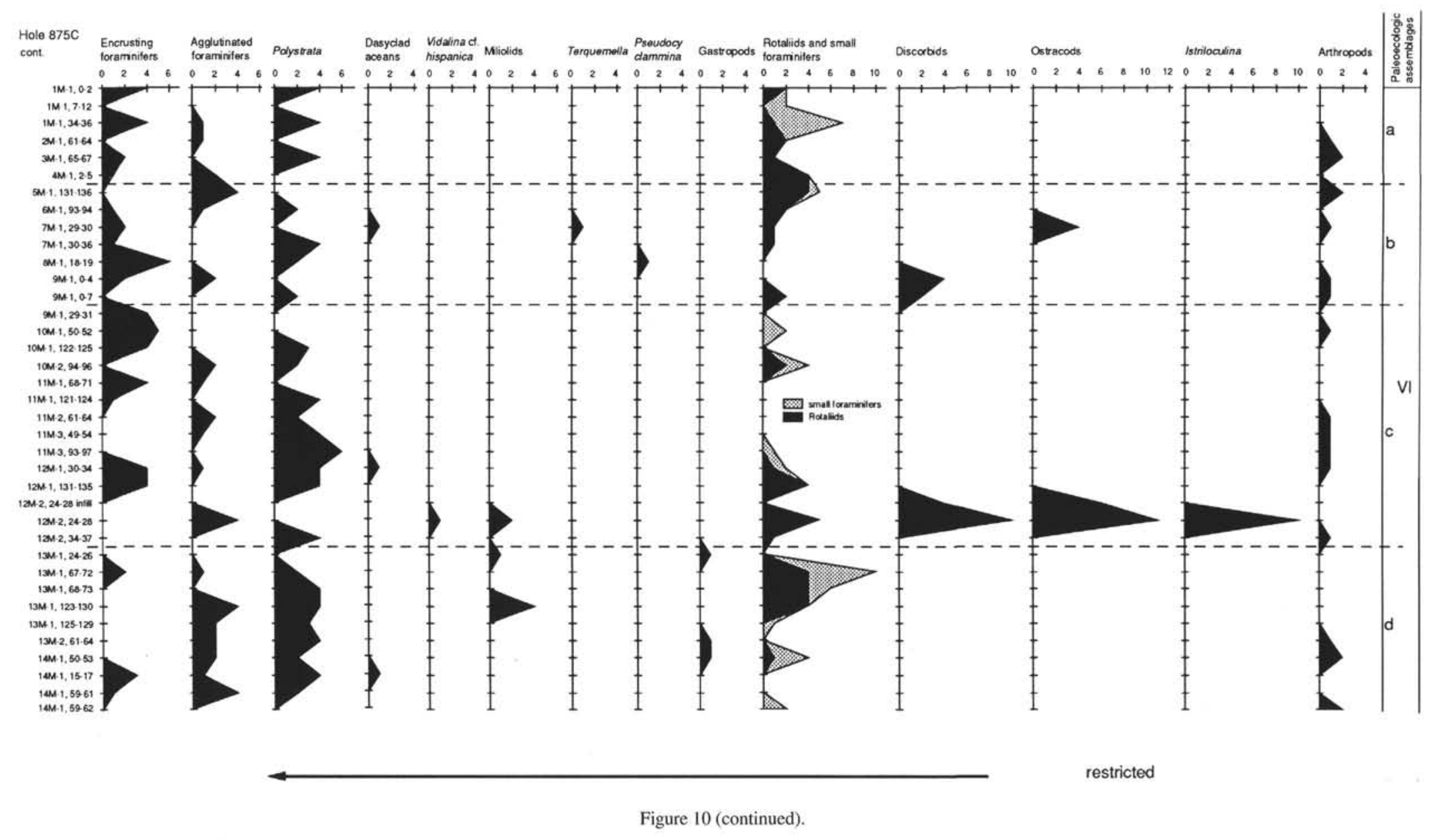

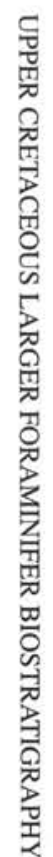




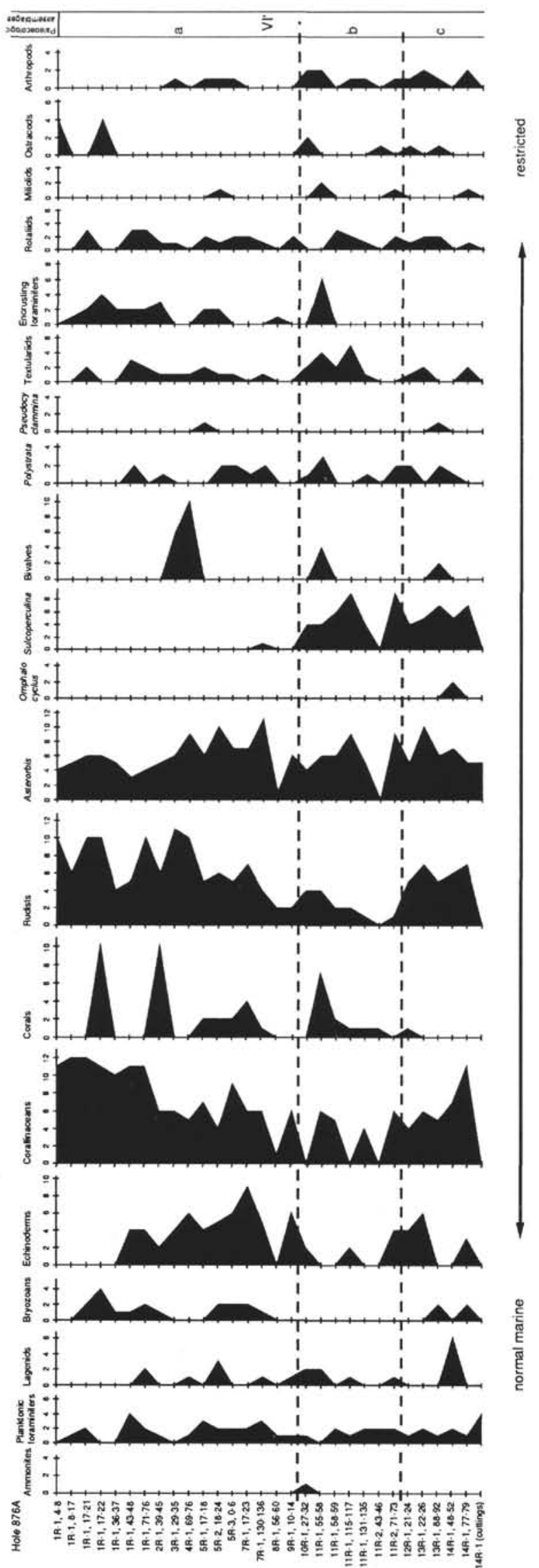

Despite the generally poor to very poor recovery of fossil assemblages, the following succession of major paleoecologic associations may be distinguished (Figs. 7-11) (from bottom to top).

\section{Lagoonal Site: Site 873}

\section{Paleoecologic Assemblage V}

Samples $144-873 \mathrm{~A}-11 \mathrm{R}-2,140-145 \mathrm{~cm}$, to $-11 \mathrm{R}-2,62-65 \mathrm{~cm}$ (= lowermost portion of lithologic Subunit IIIB)

Assemblage $\mathrm{V}$ is characterized by the occurrence of abundant pseudorbitoidids, calcareous algae, and rudists (Fig. 7 and Table 2). Benthic foraminifers include representatives of the genera Pseudorbitoides (common) and Vaughanina (rare), associated with rare to common rotaliids, discorbids (more common in the upper part of the interval), rare Dicyclina, and Marssonella. Among the algae are abundant Polystrata alba, crustose corallinacean, and rare dasycladaceans. Other organisms are common echinoderms, common to abundant bivalves, rare gastropods, and bryozoans. Discorbids, ostracodes, and sponge spicules appear in the uppermost samples, whereas Pseudorbitoides and Polystrata alba are rare or absent.

\section{Paleoecologic Assemblage IV}

Samples $144-873 \mathrm{~A}-11 \mathrm{R}-2,47-49 \mathrm{~cm}$, to $-9 \mathrm{R}-1,33-37 \mathrm{~cm}(=$ most of lithologic Subunit IIIB)

The most consistent components of Assemblage IV are rudist and bivalve fragments, echinoderms, and ostracodes, with abundant Sulcoperculina beginning above the lower one-third of the interval (see Fig. 7). Minor, but consistent, components are Dicyclina, Marssonella, small rotaliids, miliolids, and textulariids. Common Polystrata alba occurs in the lower part of the interval whereas corallinacean algae are less represented. This rich, well-diversified assemblage is separated by intervals characterized by lower diversity associations. In particular, Samples 144-873A-11R-2, 47-49 cm, to -11R-1, 130-136 $\mathrm{cm}$, are characterized by common organic matter; Samples 144-873A10R-1, 139-142 cm, to -10R-1, 92-95 cm, contain few Dicyclina and Marssonella, and rare gastropods, with some pyrite; and Samples 144-873A-9R-2, 68-71 cm, to $-9 \mathrm{R}-2,0-3 \mathrm{~cm}$, are slightly richer in ostracodes, bivalves, and rudists, but overall, benthic foraminifers are less represented. Besides the basic fossil groups mentioned above, Samples 144-873A-9R-2, 39-42 cm, to -9R-1, 78-81 cm, yielded abundant Terquemella. In the upper part of Assemblage IV, we record the uppermost occurrence of Pseudorbitoides and the last common Dicyclina.

Several samples in this interval yielded rare to few planktonic foraminifers. The most diverse fauna, which consisted of seven taxa, occurs in Samples 144-873A-10R-1, 46-50 cm, and -9R-1, 78-81 cm. Four planktonic species occur in Sample 144-873A-11R-2, 0-3 cm (see Erba et al., this volume).

\section{Paleoecologic Assemblage III}

Samples 144-873A-9R-1, 0-2 cm, to -5R-1, 41-46 cm (= upper part of lithologic Subunit IIIB and lower half of lithologic Subunit IIIA)

Assemblage III is characterized by a rhythmic distribution of associations rich in corallinacean algae, rudists, Sulcoperculina, and Asterorbis, alternating with associations rich in miliolids, gastropods, ostracodes, and discorbids, along with peaks in abundance of Istriloculina and Terquemella. The appearance of Asterobis was noted at the base of this assemblage.

Planktonic foraminifers are scattered throughout, and in Sample 144-873A-6R-1, 11-18 cm, five different taxa were recorded (see Erba et al., this volume).

\section{Paleoecologic Assemblage II}

Samples 144-873A-5R-1, 13-18 cm, to -3R-1, 3-6 cm (= upper portion of lithologic Subunit IIIA) 
Table 6. Stratigraphic ranges and relative abundance of Campanian-Maastrichtian foraminifers, calcareous algae, other organisms, mineral grains, and sedimentary features from shallow-water limestones drilled in Hole 876A (outer ridge of Wodejebato Guyot).

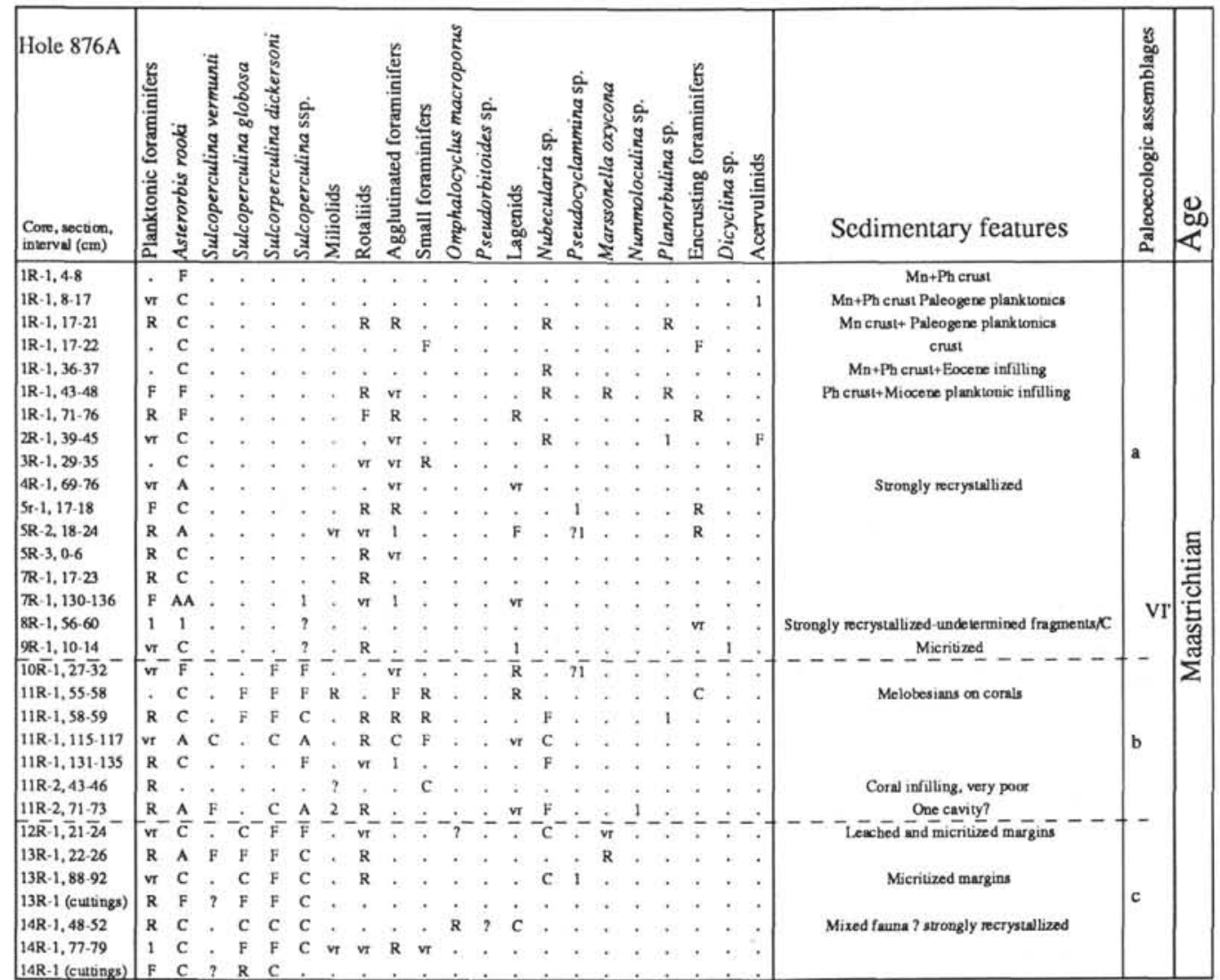

Notes: Estimated abundance as follows: \# = number of specimens, $\mathrm{vr}=$ very rare, $\mathrm{R}=$ rare, $\mathrm{F}=$ few, $\mathrm{C}=$ common, $\mathrm{A}=$ abundant, and $\mathrm{AA}=\mathrm{very}$ abundant.

Assemblage II is characterized by abundant corallinacean algae including branched taxa, rudists, and the larger foraminifers Sulcoperculina and Asterorbis. Less common components are echinoderms and miliolids. Other benthic foraminifers such as Idalina antiqua, Vidalina sp. cf. V. hispanica, Pseudocyclammina sp., and Marssonella are rare. The distribution of the various taxa, however, is uneven from layer to layer. Miliolids, Idalina antiqua, and echinoderms are more common where red algae and larger foraminifers decrease in abundance. Planktonic foraminifers were rarely observed.

\section{Paleoecologic Assemblage I}

Samples $144-873 \mathrm{~A}-2 \mathrm{R}-1,0-5 \mathrm{~cm}$, to $-1 \mathrm{R}-1,0-7 \mathrm{~cm}$, and Samples $144-$ $873 \mathrm{~B}-10 \mathrm{~N}-1,106-108 \mathrm{~cm}$, to $-8 \mathrm{~N}-1,4-8 \mathrm{~cm}$ (= uppermost portion of lithologic Subunit IIIA)

Assemblage I is characterized by the occurrence of abundant $\mathrm{Om}$ phalocyclus marcoporus associated with common to abundant Sulcoperculina and echinoderms, abundant corallinacean algae (mainly encrusting taxa), rare to abundant Polystrata alba, few ostracodes, and rare Asterorbis. Small benthic foraminifers are unevenly distributed and vary in abundance from layer to layer. Rare planktonic foraminifers occur throughout.

\section{Inner Ridge Sites}

Site 874

\section{Paleoecologic Assemblage $V$}

Samples 144-874B-20R-1, 16-22 cm, to -19R-1, 7-10 cm (= lithologic Subunit IIF)

Assemblage $\mathrm{V}$ is characterized by predominant corallinacean algae, Polystrata alba, abundant echinoderms, and common Pseudor- bitoides (Fig. 8 and Table 3). Components sporadically common in some layers are bivalves, encrusting foraminifers, miliolids, rotaliids, bryozoans, and rare corals. The two uppermost samples of this interval yielded common to abundant Sulcoperculina and few Asterorbis along with few to common Pseudorbitoides and less abundant algae. Other than in these two samples, Sulcoperculina is rare or absent. Poor preservation of foraminifer tests caused by micritization was observed frequently. Rare planktonic foraminifers are present in very few layers (see Erba et al., this volume).

This assemblage displays the same faunal and floral association as Assemblage V from Site 873.

\section{Paleoecologic Assemblage IV'}

Samples 144-874B-18R-1, 70-78 cm, to -6R-1, 127-130 cm ( lithologic Subunits IIE and IID and most of lithologic Subunit IIC)

Assemblage $\mathrm{IV}^{\prime}$ is characterized by consistently abundant Sulcoperculina, Asterorbis, and echinoderms, and corallinacean algae in variable abundance. Bivalves and rudists are scattered throughout and may be abundant. Common corals are present in the upper samples, whereas in the lower samples of the interval common branched corallinaceans and rare Terquemella were recorded. Rare miliolids and rotaliids are scattered throughout. Encrusting foraminifers are sporadically abundant. Four species of planktonic foraminifers were observed in Sample 144-874B-10R-1, 5-7 cm (see Erba et al., this volume).

Two subassemblages can be recognized: Subassemblage IV'b (Samples 144-874B-18R-1, 70-78 cm, to -16R-1, 10-12 cm) is characterized by fragmentation of most organisms; whereas in Subassemblage IV'a (Samples 144-874B-11R-1, 1-3 cm, to -6R-1, 127-130 cm), macrofossils appear predominantly as whole specimens and corallinaceans are mainly branched. Moreover, four specimens of ammonites were observed in Sample 144-874B-6R-2, 1-3 cm. Subassem- 


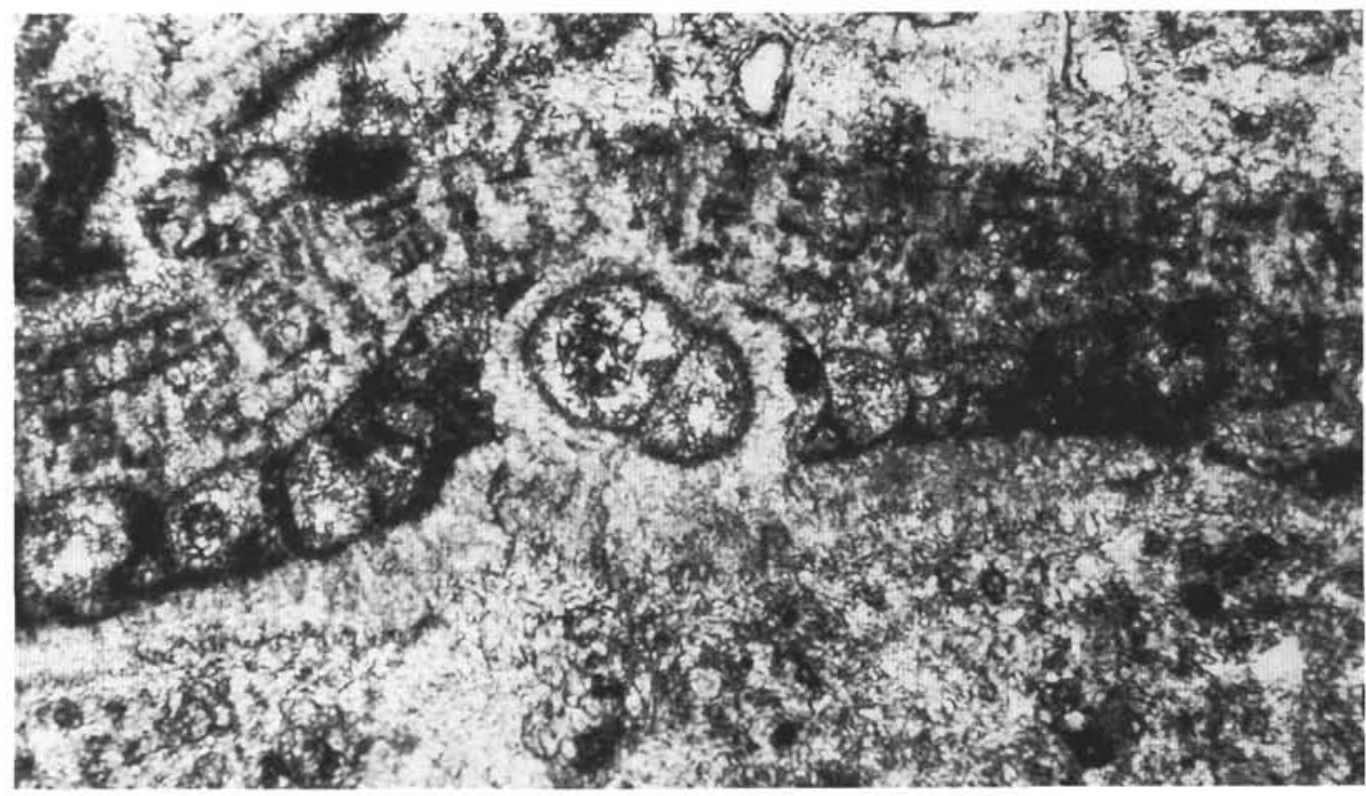

Figure 12. Orbitoides sp., form A, in limestone dredged (RD-50) from the southern slope of Wodejebato Guyot (see Lincoln et al., 1993), magnification 100x.

blage IV'a corresponds to the lower algal-coral-rudist "reef" interval of Camoin et al. (this volume).

\section{Paleoecologic Assemblage III'}

Samples $144-874 \mathrm{~B}-6 \mathrm{R}-1,8-10 \mathrm{~cm}$, to $-2 \mathrm{R}-1,19-21 \mathrm{~cm}$ (= uppermost lithologic Subunits IIC and IIB and the lower part of lithologic Subunit IIA)

Assemblage III' is characterized by abundant rudist fragments, corallinacean algae, corals, and Sulcoperculina and Asterorbis. Other important components are gastropods, ostracodes, and echinoderms, the latter more abundant in the lower samples of the interval. Minor components are discorbids, small rotaliids, and miliolids. Most of the above-mentioned components display an uneven distribution throughout the interval (Fig. 8). Distribution patterns allow us to distinguish two subassemblages. Subassemblage III'b (Samples 144-878B-6R-1, $8-10 \mathrm{~cm}$, to $-5 \mathrm{R}-1,8-14 \mathrm{~cm}$ ) contains discrete intervals with small faunas, and floras are few (Samples 144-874B-6R-1, 8-10 cm, to $-6 \mathrm{R}-1,0-4 \mathrm{~cm}$ ). These samples, in addition to the occurrence of rare oogones of charophytes, are also characterized by cavities infilled with pelagic sediments of Paleocene age.

Subassemblage III'a (Samples 144-878B-4R-1, 53-55 cm, to $-2 \mathrm{R}-1,19-21 \mathrm{~cm}$ ) displays a clearly rhythmic distribution with highly diverse associations, alternating to poorly diversified faunas, and it includes the poorest association of this subassemblage (in mudstone of Sample 144-874B-2R-1, 84-87 cm). The less diversified faunas of Subassemblage III'a consist of abundant discorbids and Istriloculina, common ostracodes, few gastropods, and scattered Vidalina sp. cf. V. hispanica.

Very rare planktonic foraminifers occur in Sample 144-874B2R-1, 19-21 cm.

\section{Paleoecologic Assemblage I}

Samples 144-874B-2R-1, 2-5 cm, to $-1 \mathrm{R}-1,18-22 \mathrm{~cm}$; and Samples 144-874A-1R-2, 16-22 cm, to -1R-1, 7-13 cm (= upper two-thirds of lithologic Subunit IIA in Holes 874A and 874B)

Assemblage I is dominated by rudists associated with abundant Sulcoperculina, Asterorbis, and corallinacean algae. Echinoderms and corals are abundant in Hole 874A along with a few chaetetids. Rare to few small benthic foraminifers including encrusting forms, rotaliids, and miliolids are sparse.
This assemblage displays the same faunal and floral association as Assemblage I from Site 873 except for the absence of Omphalocyclus macroporus. Assemblage I corresponds to the upper algal-octocoralrudist "reef" interval of Camoin et al. (this volume).

\section{Site 877}

\section{Paleoecologic Assemblage $\mathrm{V}$}

Samples 144-877A-20R-1, 77-78 cm, to -19R-1, 27-30 cm (= topmost part of lithologic Unit III and Subunit IIE)

Assemblage $\mathrm{V}$ is characterized by abundant to common Pseudorbitoides and corallinacean algae (Fig. 9). Other components are fewer rudists, echinoderms, Polystrata alba, and very rare, scattered, small benthic foraminifers and ostracodes. Sample 144-877A-20R-1, 0-7 $\mathrm{cm}$, yielded common Asterorbis. Rare planktonic foraminifers occur throughout the interval (see Erba et al., this volume). Abundant pyrite and volcanic clasts occur in the two lowermost samples, respectively.

This assemblage displays the same faunal and floral association as Assemblage V from Sites 873 and 874.

\section{Paleoecologic Assemblage III"}

Samples $144-877$ A-18R-1, 70-74 cm, to $-4 \mathrm{R}-1,43-45 \mathrm{~cm}$ (= lithologic Subunits IID and IIC)

Assemblage III" is dominated by rudists, corallinacean algae, echinoderms, Asterorbis, and Sulcoperculina. Other components are few to common Polystrata alba; bryozoans; and rare, scattered, small benthic foraminifers, corals, and bivalves. Two discrete subassemblages (III"b and III"a) can be distinguished on the basis of fossil preservation (see Fig. 9 and Table 4). In Subassemblage III"b (Samples $144-877 \mathrm{~A}-18 \mathrm{R}-1,70-74 \mathrm{~cm}$, to $-12 \mathrm{R}-1,11-17 \mathrm{~cm}$ ), the main components occur in fragments or as worn specimens. Bryozoans are common, whereas corals rarely occur. Sulcoperculinids, asterorbids, and corallinacean algae are markedly less abundant in the upper part of the interval than in the underlying part. Few planktonic foraminifers occur in Samples 144-877A-18R-1, 70-74 cm, and -18R-1, $25-28 \mathrm{~cm}$ (see Erba et al., this volume).

Subassemblage III"a (Samples 144-877A-11R-2, 62-64 cm, to $-4 \mathrm{R}-1,43-45 \mathrm{~cm}$ ) contains typically whole specimens of macrofossils and well-preserved corallinacean algae and Polystrata alba. Corals are common, whereas bryozoans are almost absent. Minor components are 

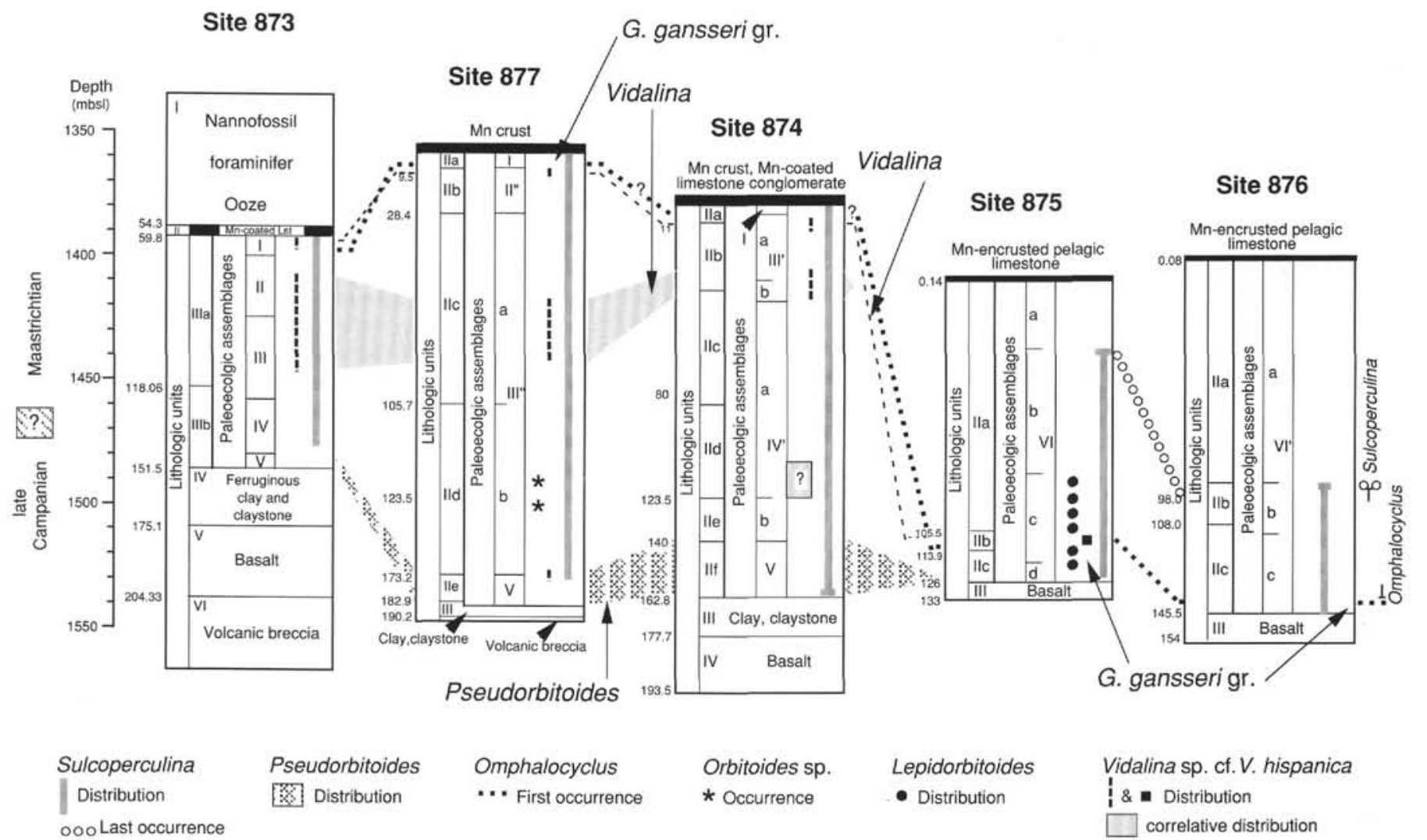

Figure 13. Correlation of the drill sites on Wodejebato Guyot.

scattered, rare to common, small benthic foraminifers. Vidalina sp. cf. V. hispanica occurs in the lower part of the interval. Few ammonites are recorded in the upper part and rare planktonic foraminifers occur throughout the entire interval (see Erba et al., this volume).

Subassemblage III" a corresponds to the lower algal-coral-rudist "reef" interval of Camoin et al. (this volume).

Subassemblages III"b and III"a display the same respective faunal and floral association and preservation as Subassemblages III'b and III'a, described at Site 874.

\section{Paleoecologic Assemblage $I I^{\prime \prime}$}

Samples 144-877A-3R-1, 130-133 cm, to -2R-1, 53-55 cm (= lithologic Subunit IIB)

Assemblage $\mathrm{II}^{\prime \prime}$ is highly depleted in organisms and consists of few rudists, echinoderms, discorbids, and rotaliids, and more common miliolids. Manganese-oxidized crust may be present.

\section{Paleoecologic Assemblage I}

Samples 144-877A-1R-2, $42-46 \mathrm{~cm}$, to $-1 \mathrm{R}-1,1-4 \mathrm{~cm}$ (= lithologic Subunit IIA)

Assemblage I is characterized by abundant Sulcoperculina, Asterorbis, rudists, corallinacean algae, few corals, and echinoderms. Other components are common miliolids and Polystrata alba; rare, scattered, small benthic foraminifers including Vidalina sp. cf. V. hispanica; ostracodes; and gastropods. Sample 144-877A-1R-1, 133$136 \mathrm{~cm}$, yielded a few specimens of Omphalocyclus macroporus. Rare planktonic foraminifers are present throughout the interval (see Erba et al., this volume). Assemblage I corresponds to the upper algaloctocoral-rudist "reef" interval of Camoin et al. (this volume).

This assemblage displays the same faunal and floral association as Assemblage I from Sites 873 and 874.

\section{Outer Ridge Sites}

The carbonate sequences of Sites 875 and 876 , located in the outer ridge of Wodejebato Guyot, were identified as shelf margin deposits (Premoli Silva, Haggerty, Rack, et al., 1993). The more open-marine environment is reflected in the faunal and floral composition. Planktonic foraminifers are more common here than they are in the lagoonal and inner ridge sites; benthic foraminifers are more diverse and include lagenids, several trochospiral (e.g., Cibicides, Eponides, Gavelinella, Nuttallides, Gyroidinoides, and Stensioina) and planispiral (nonionids) forms, and several species of agglutinants (e.g., Bolivinopsis and Dorothia). Discorbids are rare. Fragments of inoceramids were also recorded.

Shallow-water assemblages at these sites display a mixture of reworked faunas from different facies (from lagoonal to open-marine environments). Mixing is especially evident in the lower part of the sequence, characterized by poor preservation of fauna and flora.

\section{Site 875}

\section{Paleoecologic Assemblage VI}

Samples $144-875 \mathrm{C}-14 \mathrm{M}-1,59-62 \mathrm{~cm}$, to $-1 \mathrm{M}-1,0-2 \mathrm{~cm}$ (= lithologic Subunits IIC, IIB, and IIA)

The main components of Assemblage VI are fragments and grains of rudists, corallinacean algae, echinoderms, Asterorbis, and sulcoperculinids. Other components are common Polystrata alba and few to common agglutinated and rotaliid small foraminifers. Planktonic foraminifers occur throughout the assemblage (Fig. 10 and Table 5). Four subassemblages can be recognized on the basis of fluctuations in abundance of the various organisms. The lowest one, Subassemblage VId (Samples 144-875C-14M-1, 59-62 cm, to -13M-1, 24-26 $\mathrm{cm})$, best demonstrates the mixed origin of the sediments deposited 
at Site 875 . Faunas and floras are included in extraclasts, especially in the lower samples. Preservation of organisms is very uneven in the same sample, and micritized and fragmented fossils are frequent. Planktonic foraminifers are consistently present throughout the interval and are occasionally represented by rather diversified faunas (see Erba et al., this volume). Another indicator of the mixed origin is represented by the occurrence of small benthic foraminifers, which include few lagenids, several rotaliforms, and bolivinids. These forms with a more open-marine habitat occur with typically shallow-marine dwelling organisms, including abundant Pseudorbitoides at the very base, Sulcoperculina and Asterorbis along with corallinacean algae (also branched), rudists, Polystrata alba, and a possible Dicyclina higher in the interval.

Subassemblage VIc (Samples 144-875C-12M-2, 34-37 cm, to $-9 \mathrm{M}-1,29-31 \mathrm{~cm})$ is characterized by the occurrence of common Omphalocyclus macroporus, abundant Asterorbis, and possible Lepidorbitoides associated with abundant Sulcoperculina (Fig. 10). Planktonic foraminifers are constantly present, although the number of taxa did not exceed eight species identified in thin section (see Erba et al., this volume).

Peculiar in this context are Samples 144-875C-12M-2, 34-37 cm, and $-12 \mathrm{M}-2,24-28 \mathrm{~cm}$, which yielded an association characterized by very abundant ostracodes; abundant discorbids and Istriloculina; fewer valvulinids, rotaliids, and miliolids; rare echinoderms; and very rare Vidalina sp. cf. $V$. hispanica. This assemblage is considered as being included in larger lithoclasts possibly collapsed from the margin (see Enos et al. and Arnaud Vanneau et al., both in this volume).

Subassemblage VIb (Sample 144-875C-9M-1, 0-7 cm, to -5M-1, $131-136 \mathrm{~cm}$ ) is characterized by a marked decrease in abundances of orbitoidids and sulcoperculinids, whereas corals are more frequent. Terquemella and ostracodes are sporadically present (Fig. 10). Possible Inoceramus fragments occur in the lower samples of the interval.

Subassemblage VIa (Samples 144-875C-4M-1, 2-5 cm, to -1M-1, $0-2 \mathrm{~cm}$ ) is very similar to Subassemblage VIb, except for the absence of Sulcoperculina and Omphalocyclus macroporus (Fig. 10). Cretaceous planktonic foraminifers, although rare, occur throughout the top of the interval and are always associated with shallow-water organisms.

\section{Site 876}

\section{Paleoecologic Assemblage $V I^{\prime}$}

Samples 144-876A-14R-1, 77-79 cm, and "cuttings," to Sample 144 $876 \mathrm{~A}-1 \mathrm{R}-1,4-8 \mathrm{~cm}$ (= lithologic Subunits IIC, IIB, and IIA, including the shallow-water portion of the Mn-crust of lithologic Subunit I)

As at Site 875, the main components of Assemblage VI' are fragments and grains of rudists, corallinacean algae, echinoderms, Asterorbis, and sulcoperculinids (Fig. 11 and Table 6). Other components are common Polystrata alba and few to common agglutinated and rotaliform small foraminifers. Planktonic foraminifers occur throughout. Three subassemblages can be recognized on the basis of fluctuations in the abundance of various organisms.

Subassemblage VI'c (Samples 144-876A-14R-1, "cuttings," to $-12 \mathrm{R}-1,21-24 \mathrm{~cm}$ ) is characterized by abundant Asterorbis and Sulcoperculina, common rudists, and corallinacean algae. Branched corallinacean algae are very abundant in Sample 144-876A-14R-1, $77-79 \mathrm{~cm}$. Other components are rare echinoderms, bryozoans, Polystrata alba, and small benthic foraminifers. Omphalocyclus macroporus occurs in Sample 144-876A-14R-1,48-52 cm, and possibly in Sample 144-876A-12R-1, 21-24 cm, where uncertain Lepidorbitoides is also recorded. Pseudorbitoides is remarkably absent. Common and diverse lagenids are present in Sample 144-876A-14R-1, $48-52 \mathrm{~cm}$. Planktonic foraminifers are rather common in almost all layers and display a moderate diversity (see Erba et al., this volume).

Subassemblage VI'b (Sample 144-876A-11R-2, 71-73 cm, to $-10 \mathrm{R}-1,27-32 \mathrm{~cm}$ ) is characterized by common to very abundant
Asterorbis and Sulcoperculina progressively decreasing in abundance upward, especially sulcoperculinids. Corallinacean algae, poorly represented at the base, become progressively more abundant upward. Echinoderms and corals are only sporadically common, mainly in the upper samples of the interval. Rudists are rare throughout. Small benthic foraminifers are scattered and rare, except for encrusting forms and textulariids, which are more common. Rare planktonic foraminifers are scattered throughout the interval. A single ammonite was found in Sample 144-876A-10R-1, 27-32 cm.

Subassemblage VI'a (Sample 144-876A-9R-1, 10-14 cm, to -1R$1,4-8 \mathrm{~cm}$ ) is characterized by very abundant corallinacean algae, rudists, and Asterorbis in the absence of Sulcoperculina. Echinoderms, common to abundant in the lower samples, progressively decrease in abundance upward, and they are absent in the uppermost part. Bryozoans are consistently present although rare. Corals are sporadically abundant. Small benthic foraminifers are diverse but few to rare overall. Planktonic foraminifers occur consistently but are poorly diversified and rare.

\section{Tentative Correlations and Interpretation}

The assemblages described above can be interpreted in paleoecological terms, and relative water depths have been estimated according to the modern depth distribution of larger foraminifers and associated organisms from a warm-water environments such as the Gulf of Aqaba (see Hottinger, 1983; Reiss and Hottinger, 1984). The five sites drilled on Wodejebato Guyot are located along an ideal transect from the inner lagoon (Site 873) to the shelf margin (Sites 875 and 876). Sites 874 and 877 are located where reef build-up was expected to occur. As expected, Site 873 experienced the most restricted environmental conditions of the entire sequence of Wodejebato Guyot. Knowing the real spacial and temporal relationships of the drilled sites, despite the poor to very poor recovery, we can at least tentatively correlate the paleoecologic assemblages from site to site (Fig. 13). The inner ridge sites ( 874 and 877 ) and the outer ridge sites ( 875 and 876$)$ are intuitively easier to correlate. The correlation between the inner ridge sites and the lagoonal site (873), however, is more difficult. It is even more difficult to correlate Sites 873,874 , and 877 to the outer ridge sites.

Correlatable paleoecologic assemblages were coded by the same number in all sites in which they were identified, using ' and " to identify the primary and secondary sites, respectively (Figs. 7-11 and Tables 2-6).

Assemblage V, which recorded the initial transgressive phase on the volcanic substrate and its weathered profile, was recognized with certainty at the lagoonal site (873) and inner ridge sites (874 and 877) (Fig. 13). The difference from site to site is mainly confined to the thickness of the sediments yielding the assemblage. The pioneer community (common rhodoliths and encrusting red algae) is also better developed at Site 877 and especially at Site 874 than it is at Site 873. Evidence of Assemblage V also occurs at outer ridge Site 875 in the lowermost Subassemblage VId where, however, the faunal and floral elements of this assemblage are mixed with organisms of younger age (see below). Assemblages $\mathrm{III}^{\prime}$ and $\mathrm{III}^{\prime \prime}$ at Sites 874 and 877, representing the lower algal-coral-rudist "reef" interval and the associated sandy facies (see Camoin et al., this volume), indicate that the carbonate platform grew similarly at these two sites, even if some lateral changes are detectable owing to the difference in thickness (see Premoli Silva, Haggerty, Rack, et al., 1993). The floral and faunal elements of these assemblages also occur in the lagoonal site, but they alternated with less open-marine-dwelling organisms (= Assemblage III). Moreover, more open-marine conditions are recorded in the topmost Assemblage I at all the three sites, just preceded by the shallowest and most restricted environments (Assemblage II) of the evolution of Wodejebato carbonate platform. The floral and faunal associations at the three sites obviously are not identical. At Site 873, 
common large foraminifers, encrusting algae, and rare planktonic foraminifers characterize Assemblage I, whereas the second coralalgal-rudist "reef" developed at Sites 874 and 877 (Fig. 13).

As mentioned above, the entire carbonate succession yielded only one paleoecologic assemblage at both outer ridge sites ( 875 and 876). It was characteristic of shelf margin deposits, composed of a mixture of reworked faunas and floras from different environments spanning restricted lagoonal to open-marine conditions and containing rather common planktonic foraminifers throughout. It was demonstrated, using age correlations (Fig. 13), that the succession at both outer ridge sites is younger than those at the lagoonal and inner ridge sites. As such, it is not represented there. On the other hand, most of the correlatable horizons, identified in lagoonal and inner ridge sites, cannot be extended to Sites 875 and 876 .

The only questionable record concerns Subassemblage IVd at Site 875 , which yielded some faunal elements characteristic of the basal Assemblage V of Sites 873,874 , and 877 (especially the pseudorbitoidids). The poor recovery prevented the clarification of whether this horizon is at least partially in place or is totally a result of reworking. The lower part of the carbonate succession at Site 875, which yielded Subassemblage IVd, could be correlated on the basis of fossil content, but only to the top of the lagoonal and inner ridge sequences. In our opinion, however, this interpretation seems unlikely.

\section{Evolution of Wodejebato Carbonate Platform}

After the Late Cretaceous (Campanian according to Pringle and Duncan, this volume) episode of volcanism, the volcanic island of Wodejebato subsided. It was flooded in the late Campanian under shallow-marine conditions, as corroborated by the occurrence of calcareous nannofossils at the very base of the shallow-water succession at Sites 873 and 877. A substantial carbonate platform became established shortly later in the late Campanian with a relatively deepwater environment covering the edifice. Red algae appear as the pioneer colonizers of the muddy substrate, which rapidly was fully colonized. The carbonate platform continued to grow, and the edges of the platform became the location of modest, temporary bioconstructions early in the Maastrichtian. The lagoonal facies (Site 873) are alternatively represented by rudist and algal-rich to miliolid-rich or Istriloculina-discorbid-rich biotopes. After this brief episode, shallower water conditions affected both the lagoonal and platform edges at Wodejebato. This trend continued and brought the platform to temporary emersion. Soon after this, however, deeper water and more open-marine conditions resumed even over the center of the lagoon, and the edges again became the location of new, modest bioconstructions. No younger shallow-water sediments are preserved in the lagoonal and inner ridge sites. Carbonate sedimentation, however, continued at Wodejebato, as demonstrated by the shelf margin deposits recovered at the outer ridge sites ( 875 and 876$)$. It is likely that carbonate sediments were still deposited in the lagoon and on the inner ridge sites during that time, but they were subsequently eroded and contributed to the sediment accumulation at the outer ridge sites. Shallow-water carbonate sedimentation at Wodejebato ceased before the end of the Maastrichtian, as indicated by the pelagic infilling of Maastrichtian age at the top of the carbonate succession (see Watkins et al., this volume), although the carbonate factory continued to be active until late in the Maastrichtian.

Shortly after its demise in the late Maastrichtian, the Wodejebato platform sank quickly below the photic zone. The early late Paleocene calcareous plankton (nannofossil Zone CP4 and planktonic foraminifer Subzone P3b) (or earliest Paleocene nannofossil Subzone CP1a and planktonic foraminifer Zone $P \alpha$ ?), recorded from the capping manganese crust, indicate that shortly after the cessation of the shallow-water carbonate sedimentation, Wodejebato Guyot was under an open-marine, oceanic environmental regime. The hiatus associated with the disconformity between the carbonate platform and the condensed pelagic sediments can be estimated as not exceeding $3-4 \mathrm{~m}$. y. according to the adopted time scale (see Premoli Silva, Haggerty, Rack, et al., 1993; Erba et al., this volume).

\section{LIST OF FORAMINIFER SPECIES}

\author{
Asterorbis rooki Vaughan and Cole \\ Dicyclina sp. cf. D. schlumbergeri Munier-Chalmas \\ Gansserina gansseri (Bolli) \\ Idalina antiqua Schlumberger and Munier-Chalmas \\ Marsonella oxycona (Reuss) \\ Omphalocyclus macroporus (Lamarck) \\ Orbitoides sp. \\ Pseudorbitoides trechmanni Douvillé \\ Sulcoperculina dickersoni (Palmer) \\ Sulcoperculina globosa de Cizancourt \\ Sulcoperculina obesa de Cizancourt \\ Sulcoperculina vermunti (Thiadens) \\ Vidalina sp. cf. V. hispanica Schlumberger
}

\section{ACKNOWLEDGMENTS}

The authors are indebted to the Ocean Drilling Program for having invited two of them (IPS and AAV) to participate on Leg 144. We would like to thank all of the scientists who contributed to the study of Wodejebato Guyot and the technicians who prepared the thin sections and took the burden of collecting even the tiniest chips out of our poor material. Our warm thanks go also to J.P. Krijnen and E. Caus for the careful review of this paper, and to D. Basso and C. Corselli for the helpful discussion on paleoecology of shallow-water organisms. From the University of Milano, G. Chiodi printed the photomicrographs and C. Malinverno made some new thin sections. This research was financially supported by a Consiglio Nazionale delle Ricerche grant to IPS (A192.00283.05) and a grant from the Consiglio Nazionale delle Ricerche for ODP Research to M.B. Cita (CT93.01025.CT05).

\section{REFERENCES ${ }^{*}$}

Ellis, B.F., and Messina, A.R., 1966-1967. Catalogue of Index Foraminifera: New York (American Museum of Natural History).

Hottinger, L., 1983. Processes determining the distribution of larger Foraminifera in space and time. Utrecht Micropaleontol. Bull., 30:239-253.

Krijnen, J.P., 1972. Morphology and phylogeny of pseudorbitoid foraminifera from Jamaica and Curaçao, a revisional study. Scripta Geol., 8.

Krijnen, J.P., MacGillavry, H.J., and van Dommelen, H., 1993. Review of Upper Cretaceous orbitoidal larger foraminifera from Jamaica, West Indies, and their connection with rudist assemblages. In Wright, R.M., and Robinson, E. (Eds.), Biostratigraphy of Jamaica. Geol. Soc. Am. Mem., 182:29-63.

Larson, R.L., Schlanger, S.O., et al., 1981, Init. Repts. DSDP, 61: Washington (U.S. Govt. Printing Office).

Lincoln, J.M., Pringle, M.S., and Premoli-Silva, I., 1993. Early and Late Cretaceous volcanism and reef-building in the Marshall Islands. In Pringle, M.S., Sager, W.W., Sliter, W.V., and Stein, S. (Eds.), The Mesozoic Pacific: Geology, Tectonics, and Volcanism. Geophys. Monogr., Am. Geophys. Union, 77:279-305.

McArthur, J.M., Kennedy, W.J., Gale, A.S., Thirlwall, M.F., Chen, M., and Hanncock, J.M., 1992. Strontium isotope stratigraphy in the Late Cretaceous intercontinental correlation of the Campanian/Maastrichtian boundary. Terra Nova, 4:385-393.

McArthur, J.M., Thirlwall, M.F., Chen, M., Gale, A.S., and Kennedy, W.J., 1993. Strontium isotope stratigraphy in the Late Cretaceous: numerical calibration of the $\mathrm{Sr}$ isotope curve and intercontinental correlation for the Campanian. Paleoceanography, 8:859-873.

Neumann, M., 1993. Le genre Orbitoides. II. Revision des différentes espèces. Rev. Micropaleontol., 36:301-353.

\footnotetext{
- Abbreviations for names of organizations and publications in ODP reference lists follow the style given in Chemical Abstracts Service Source Index (published by American Chemical Society).
} 
Premoli Silva, I., 1986. A new biostratigraphic interpretation of the sedimentary record recovered at Site 462, Leg 61, Nauru Basin, western equatorial Pacific. In Larson, R.L., Schlanger, S.O., et al., Init. Repts. DSDP, 61: Washington (U.S. Govt. Printing Office), 311-319.

Premoli-Silva, I., and Brusa, C., 1981. Shallow-water skeletal debris and larger foraminifers from Deep Sea Drilling Project Site 462, Nauru Basin, western equatorial Pacific. In Larson, R.L., Schlanger, S.O., et al., Init. Repts. DSDP, 61: Washington (U.S. Govt. Printing Office), 439-473.

Premoli Silva, I., Haggerty, J., Rack, F., et al., 1993. Proc. ODP, Init. Repts., 144: College Station, TX (Ocean Drilling Program).

Premoli Silva, I., and Sliter, W.V., 1994. Cretaceous planktonic foraminiferal biostratigraphy and evolutionary trends from the Bottaccione Section, Gubbio, Italy. Palaeontogr. Ital., 81:2-90.

Reiss, Z., and Hottinger, L., 1984. The Gulf of Aqaba: ecological micropaleontology. In Billings, W.D., Golley, F., et al. (Eds.), Ecological Studies: Berlin (Springer-Verlag).

van Gorsel, J.J., 1978. Late Cretaceous orbitoidal foraminifera. In Hedley, R.H., and Adams, C.G. (Eds.), Foraminifera (Vol. 3): London (Academic Press), 1-120.

Van Hinte, J.E., 1976. A Cretaceous time scale. AAPG Bull., 60:498-516.
Date of initial receipt: 1 February 1994

Date of acceptance: 15 September 1994

Ms 144SR-014

\section{APPENDIX}

Orbitoides sp.

Figure 12; Plate 2, Figs. 4 and 5

Two specimens of Orbitoides sp. in axial section were observed in Samples 144-877A-18R-1, 25-28 cm, and -15R-1, 22-26 cm. Several specimens of the same species were previously recovered in one dredge sample (RD 50) from the southern slope of Wodejebato Guyot and illustrated in Lincoln et al. (1993). The latter authors attributed the dredged specimens to Orbitoides tissoti. However, the dimensions of the macrosphere (maximum diameter 1.8-2.4 $\mathrm{mm})$ and the thickness of the surrounding calcitic wall $(0.4 \mathrm{~mm})$ exhibit values close to those of Orbitoides medius from the classical European localities of late Campanian to early Maastrichtian age. The shape of the equatorial chambers in axial section is consistent with this age attribution (see Neumann, 1993). 

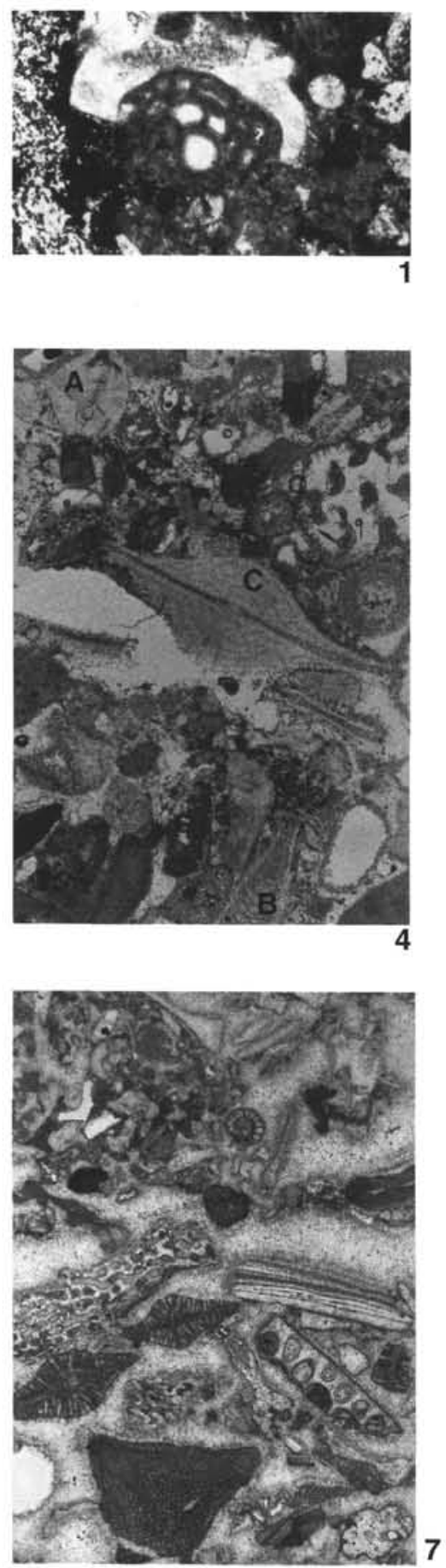
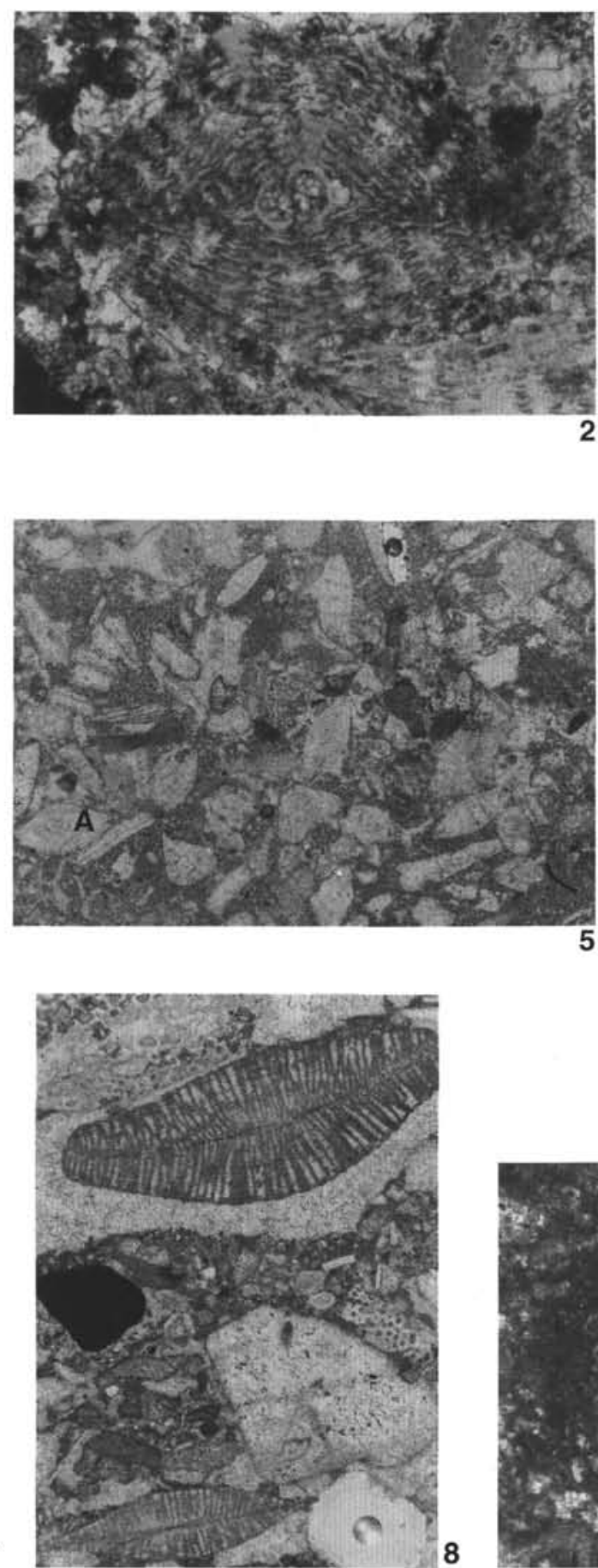

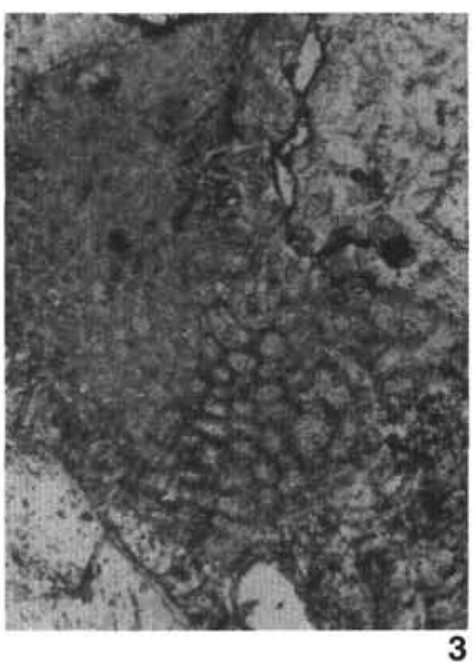

3
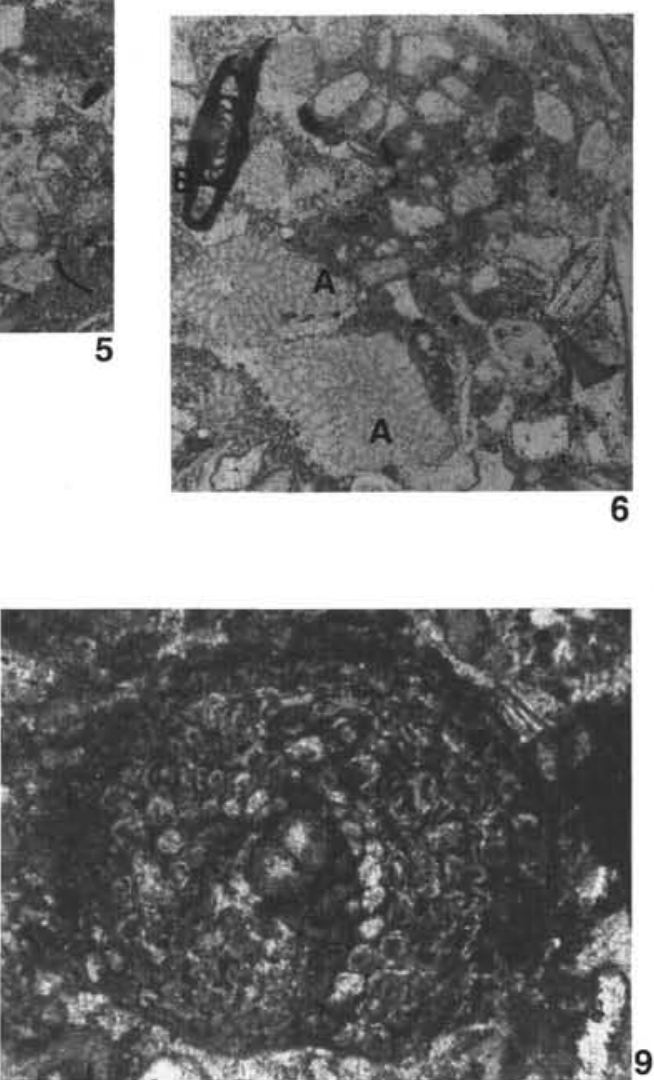

Plate 1. 1. Embryonic chambers of Pseudorbitoides trechmanni, form A. Sample $144-877$ A-20R-1, $18-20 \mathrm{~cm} .37 \times$. 2. Pseudorbitoides trechmanni, form A, axial section. Sample 144-877A-19R-1, 27-30 cm. 50x. 3. Pseudorbitoides trechmanni, form A, oblique equatorial section. Sample 144-877A-19R-1, 27-30 $\mathrm{cm}$. 50x. 4. Bioclastic packstone: (A) Sulcoperculina globosa, axial section; (B) Asterorbis?, oblique section; and (C) possible Vaughanina sp. Sample 144-877A-18R-1,70-74 cm. 20x. 5. Bioclastic packstone with abundant Sulcoperculina and Asterorbis. (A) Sulcoperculina vermunti. Sample 144-877A-8R-1, $58-61 \mathrm{~cm} .10 \times$. 6. Bioclastic packstone with (A) Asterorbis and (B) Vidalina sp. cf. V. hispanica. Sample 144-877A-8R-1, 58-61 cm. 20X. 7. Bioclastic packstone with Asterorbis, small foraminifers, and dasycladacean and rudist fragments. Sample 144-877A-5R-1, 8-14 cm. 6×. 8. Bioclastic packstone with Asterorbis, dasycladaceans, echinoderms, and ?encrusting algae. Sample 144-877A-4R-1, 124-128 cm. 12×. 9. Omphalocyclus macroporus, slightly oblique equatorial section. Sample 144-877A-1R-1, 133-136 cm. 50x. 

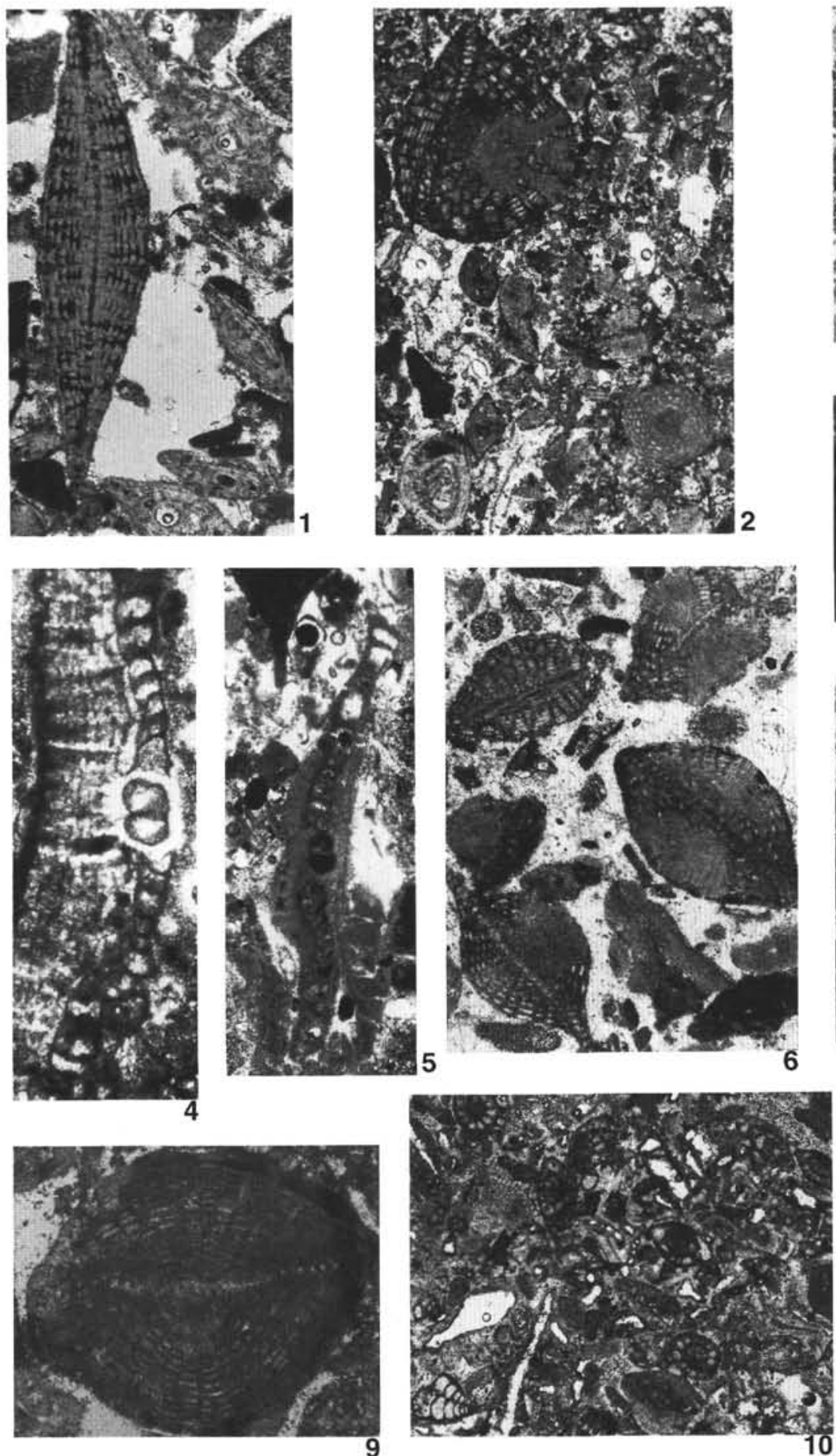
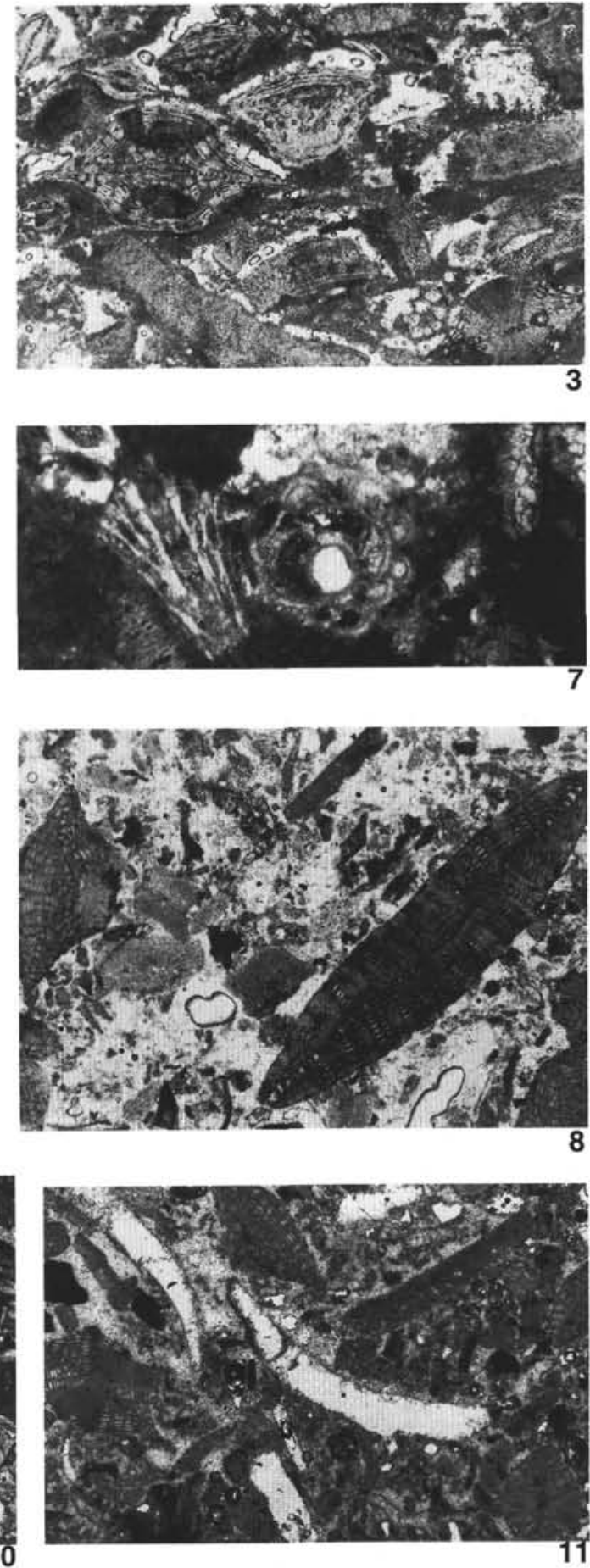

Plate 2. 1. Bioclastic packstone with abundant Pseudorbitoides. Sample 144-874B-20R-1, 16-22 cm. 25x. 2. Bioclastic packstone with Asterorbis and Sulcoperculina. Sample 144-874B-19R-1, 133-137 cm. 15×. 3. Bioclastic packstone with Pseudorbitoides, Vaughanina, Asterorbis, and Polystrata alba. Sample 144-874B-19R-1, 120-125 cm. 14x. 4. Orbitoides sp., form A, in limestones recovered in dredge sample RD-50 from the southern slope of Wodejebato Guyot (Lincoln et al., 1993). 5. Orbitoides sp., form A. Sample 144-877A-15R-1, 22-26 cm. 30x. 6. Bioclastic packstone with abundant Pseudorbitoides, Asterorbis, and echinoderm spines. Sample 144-874B-19R-1, 70-73 cm. 15x. 7. Pseudorbitoides trechmanni, form A, embryonic chambers. Sample 144-874B-19R-1, 120-125 cm. 50x. 8. Bioclastic packstone with Pseudorbitoides, Asterorbis, and Polystrata alba. Sample 144-874B-19R-1, 70-73 cm. 13×. 9. Pseudorbitoides sp. Sample 144-874B-19R-1, 34-38 cm. 20x. 10. Bioclastic packstone with abundant, mainly micritized Sulcoperculina and small foraminifers. Sample 144-874B-19R-1, 7-10 cm. 13X. 11. Bioclastic packstone with abundant $P$ seudorbitoides sp. Sample 144-874B-19R-1, 79-82 cm. 14X. 

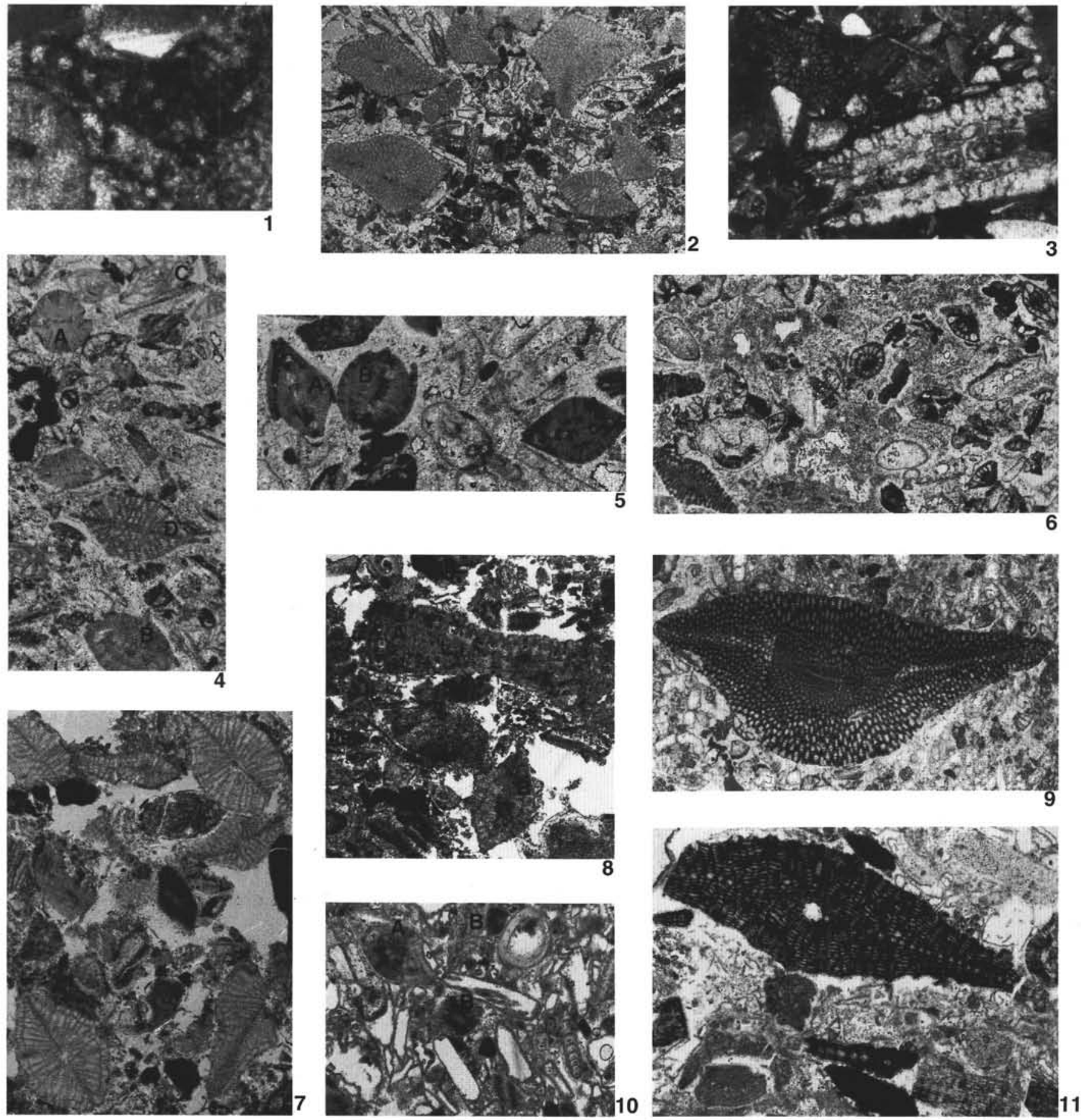

Plate 3. 1. Dicyclina sp. cf. D. schlumbergeri, embryonic chambers. Sample 144-874B-6R-1, 127-130 cm. 50x. 2. Bioclastic packstone with abundant Asterorbis rooki. Sample 144-874B-3R-3, 118-120 cm. 10X. 3. Bioclastic packstone with Asterorbis and dasycladacean. Sample 144-874B-3R-1, 51-54 cm. 13x. 4. Bioclastic packstone with Asterorbis and Sulcoperculina. (A) Sulcoperculina obesa, (B) Sulcoperculina globosa, (C) Sulcoperculina vermunti, and (D) Asterorbis. Sample 144-874A-1R-2, 16-22 cm. 11×. 5. Bioclastic packstone with (A) Sulcoperculina vermunti and (B) Sulcoperculina obesa. Sample 144-874A-1R-1, 115-120 cm. 18×. 6. Bioclastic packstone with Asterorbis and Sulcoperculina. Sample 144-874A-1R-1, 27-30 cm. 10×. 7. Bioclastic packstone with abundant Asterorbis rooki. Sample 144-875C-10M-1,50-52 cm. 13×. 8. Bioclastic packstone with (A) Omphalocyclus macroporus, (B) Asterorbis, and small foraminifers. Sample 144-875C-10M-2, 94-96 cm. 13×. 9. Bioclastic packstone with Lepidorbitoides?, small foraminifers, and Sulcoperculina. Sample 144-876A-11R-1, 58-59 cm. 9x. 10. Bioclastic packstone with (A) Sulcoperculina vermunti, (B) Asterorbis, and small foraminifers. Sample 144-875C-11M-3, 49-54 cm. 15×. 11. Bioclastic packstone with a possible Asterorbis rooki and Sulcoperculina. Sample 144-875C-11M-3, 49-54 cm. 15×. 


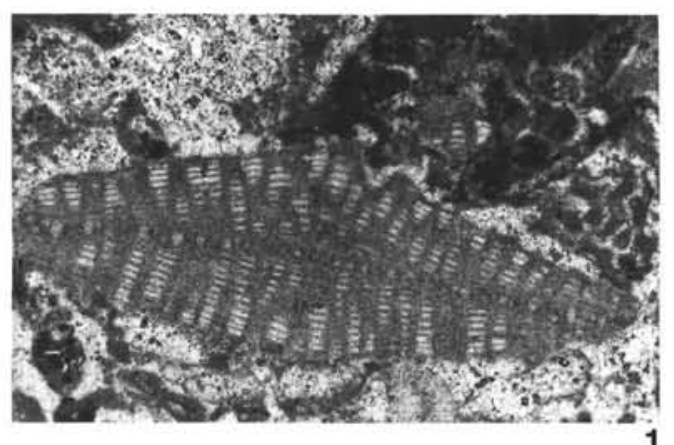

1
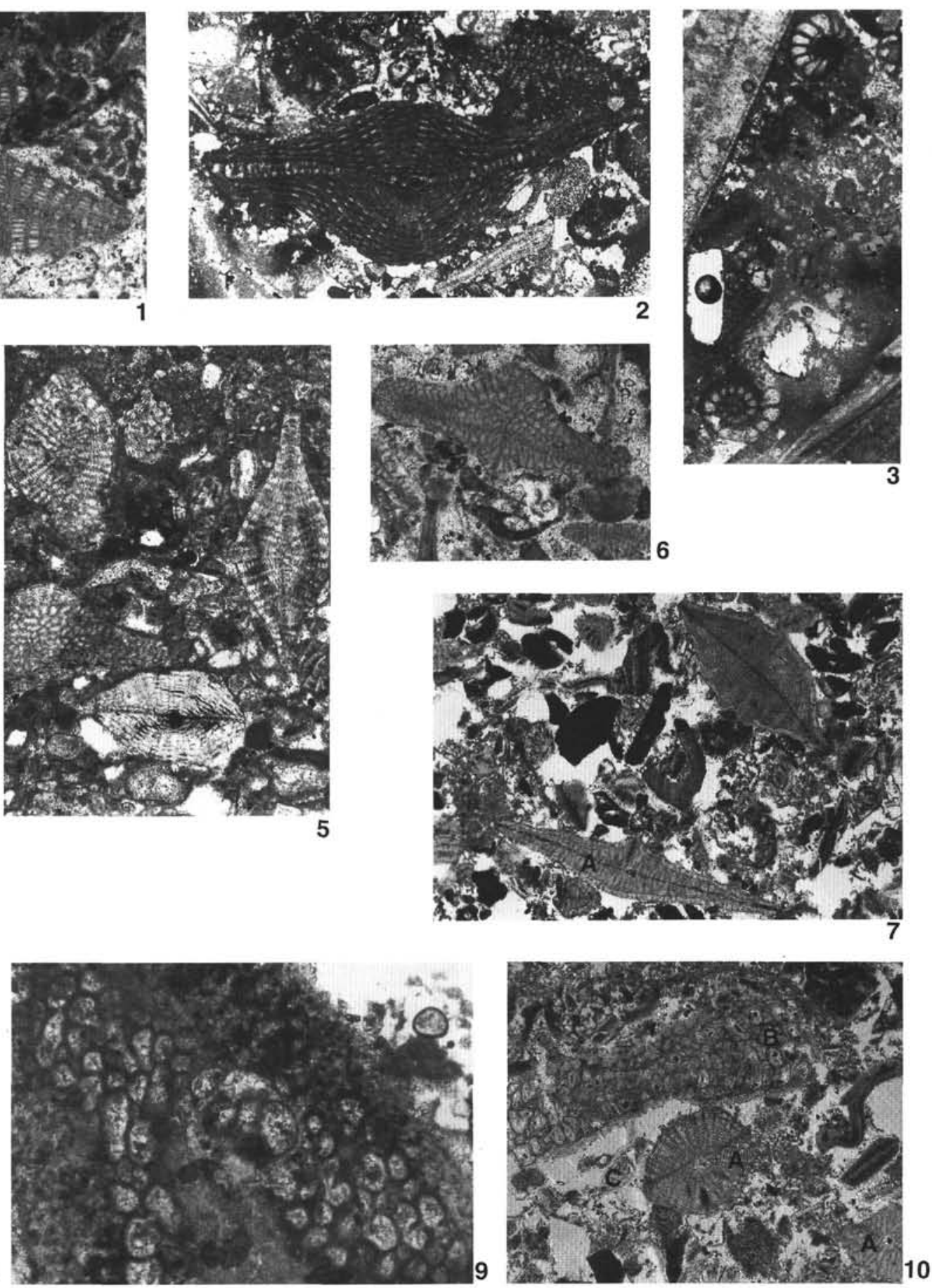

Plate 4. 1. Bioclastic packstone with Asterorbis. Sample 144-875C-14M-1,59-61 cm. 20x. 2. Bioclastic packstone with Asterorbis. Sample 144-875C-13M1, 123-130 cm. 15×. 3. Bioclastic packstone with small foraminifers. Sample 144-875C-13M-1, 123-130 cm. 20x. 4. Bioclastic packstone with Asterorbis rooki. Sample 144-875C-13M-2, 61-64 cm. 15x. 5. Bioclastic packstone with Asterorbis rooki. Sample 144-875C-13M-1, 67-72 cm. 17×. 6. Bioclastic packstone with Asterorbis rooki. Sample 144-875C-13M-2,61-64 cm. 13×. 7. Bioclastic packstone with (A) Lepidorbitoides?, Asterorbis, and Sulcoperculina. Sample 144-875C-12M-1, 30-34 cm. 9×. 8. Bioclastic packstone with Asterorbis and (A) Omphalocyclus macroporus. Sample 144-875C-11M-1, 121-124 $\mathrm{cm} .9 \times$. 9. Omphalocyclus macroporus, embryonic chambers. Sample 144-875C-11M-1, 68-71 cm. 50x. 10. Bioclastic packstone with (A) Asterorbis, (B) Omphalocyclus macroporus, and (C) Sulcoperculina dickersoni. Sample 144-875C-10M-1, 50-52 cm. 13×. 

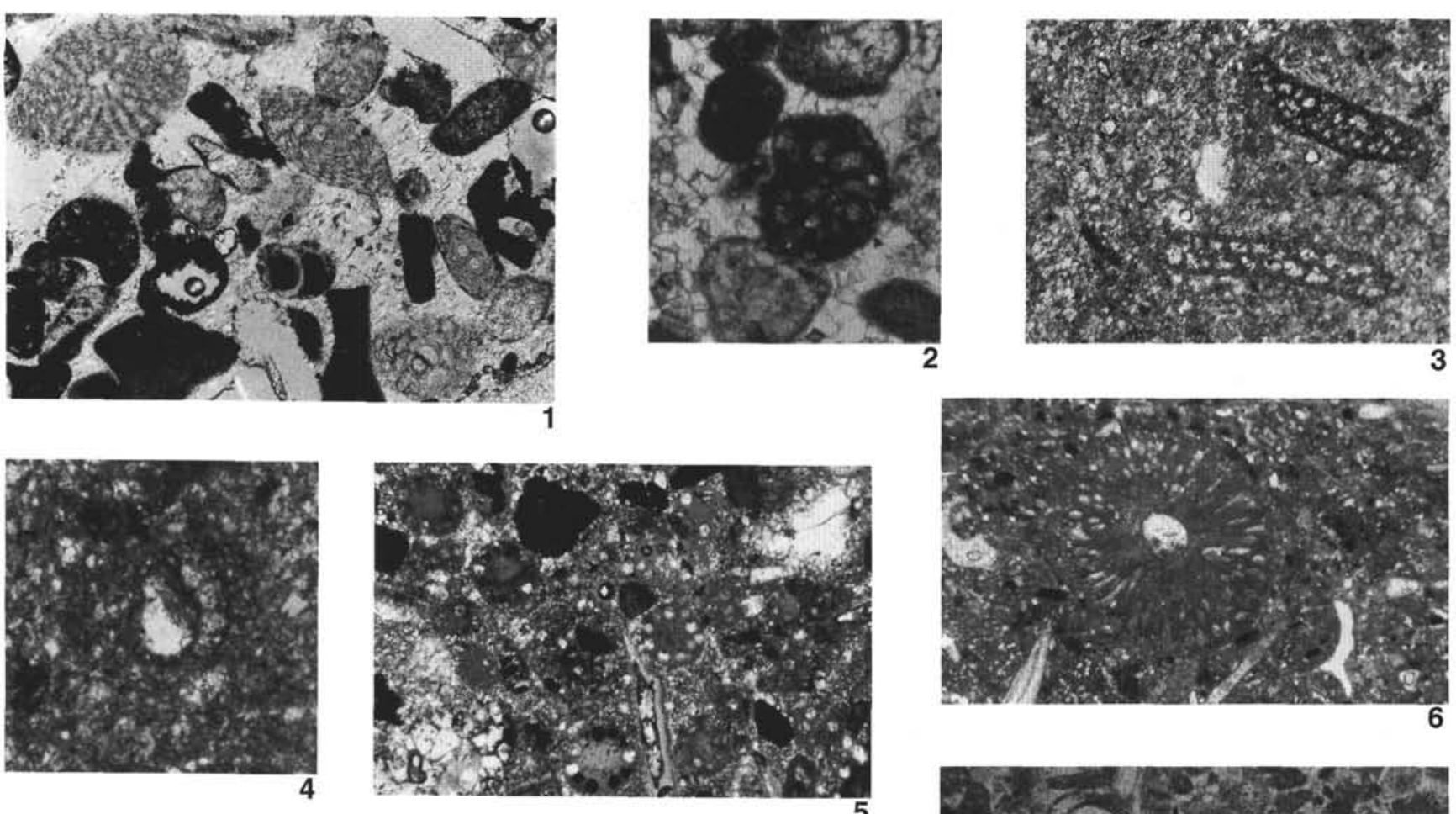

5
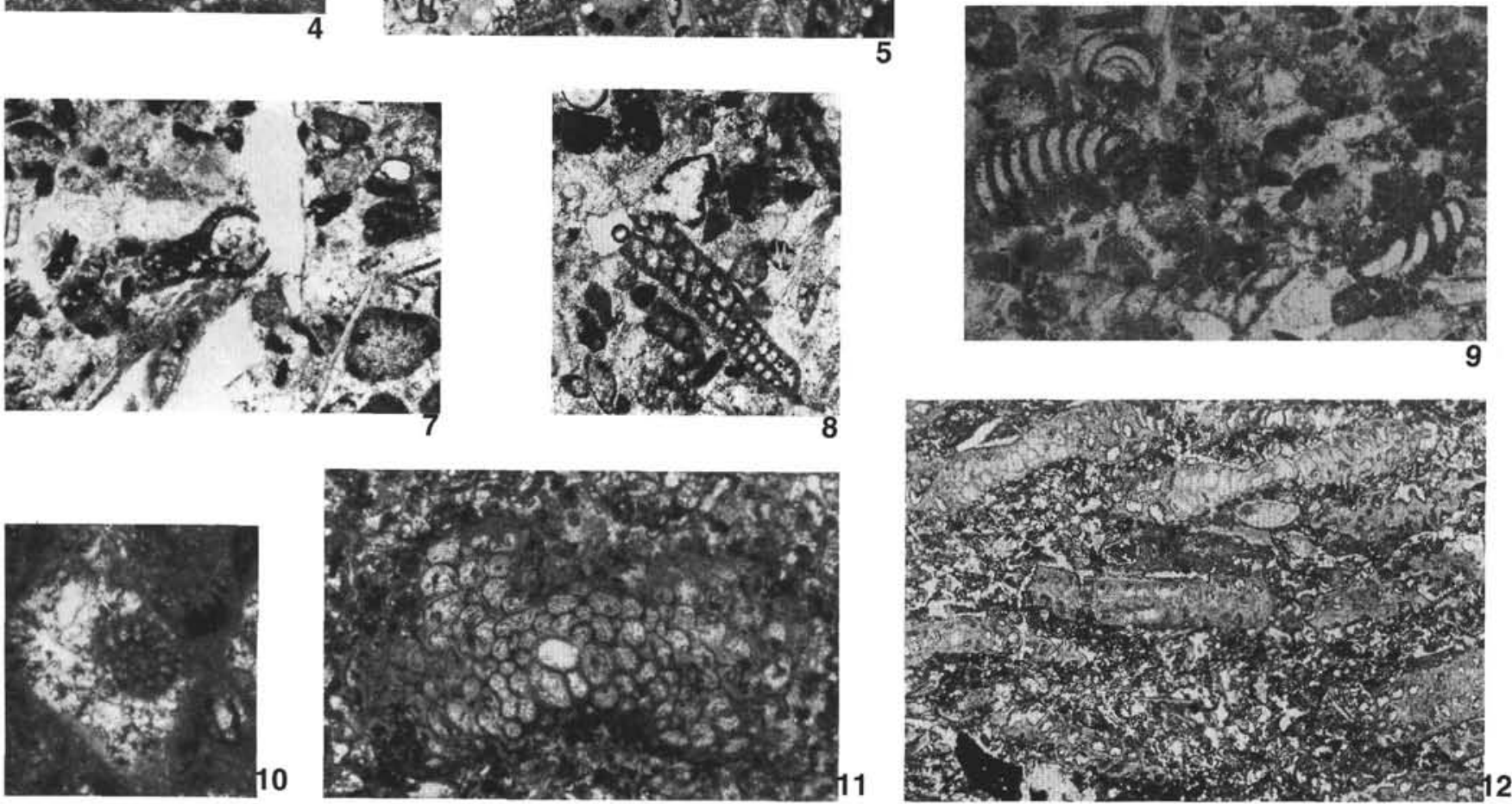

Plate 5. 1. Bioclastic packstone with Asterorbis rooki and corallinacean algae. Sample $144-873 \mathrm{~A}-11 \mathrm{R}-2,135-139 \mathrm{~cm}$. $24 \times$. 2. Small agglutinated foraminifer. Sample 144-873A-10R-1, 24-27 cm. 50x. 3. Dicyclina sp. cf. D. schlumbergeri. Sample 144-873A-9R-2, 68-71 cm. 25x. 4. Dicyclina sp. cf. D. schlumbergeri, embryonic chambers. Sample 144-873A-9R-2, 68-71 cm. 50x. 5. Bioclastic packstone with abundant Terquemella. Sample 144-873A-9R-2, 0-3 cm. 50x. 6. Bioclastic packstone with Cymopolia. Sample 144-873A-9R-2, 0-3 cm. 12×. 7. Bioclastic packstone with Dicyclina sp. cf. D. schlumbergeri, embryonic chambers. Sample 144-873A-9R-1,33-37 cm. 25×. 8. Bioclastic packstone with Dicyclina sp. cf. D. schlumbergeri. Sample 144-873A-9R-1,33-37 $\mathrm{cm} .30 \times$ 9. Bioclastic packstone with Montsechiana sp. and small foraminifers. Sample 144-873A-5R-1, 78-82 cm. 20x. 10. Small agglutinated foraminifer. Sample 144-873A-5R-1, 75-79 cm. 50x. 11. Omphalocyclus macroporus, embryonic chambers. Sample 144-873B-9N-1, 130-135 cm. 50×. 12. Bioclastic packstone with abundant oriented Omphalocyclus macroporus. Sample 144-873B-8N-2, 71-73 cm. 10x. 